University of Florida Levin College of Law

UF Law Scholarship Repository

UF Law Faculty Publications

Faculty Scholarship

2016

\title{
The Same River Twice: A Brief History of How the 1968 Florida Constitution Came to Be and What it Has Become
}

Mary E. Adkins

University of Florida Levin College of Law, adkinsm@law.ufl.edu

Follow this and additional works at: http://scholarship.law.ufl.edu/facultypub

Part of the State and Local Government Law Commons

\section{Recommended Citation}

Mary E. Adkins, The Same River Twice: A Brief History of How the 1968 Florida Constitution Came to Be and What it Has Become, 18 Fla. Coastal L. Rev. 5 (2016), available at

This Article is brought to you for free and open access by the Faculty Scholarship at UF Law Scholarship Repository. It has been accepted for inclusion in UF Law Faculty Publications by an authorized administrator of UF Law Scholarship Repository. For more information, please contact averyle@law.ufl.edu, kaleita@law.ufl.edu. 


\title{
The Same River Twice: A Brief History Of how the 1968 Florida Constitution Came To Be and What It Has Become
}

\author{
Mary E. Adkins*
}

In 1968, Florida's voters adopted a nearly complete revision of the Florida Constitution; the resulting document was Florida's sixth constitution. ${ }^{1}$ That constitution provided four ways by which it could be amended; one was a method unique to Florida then and now. ${ }^{2}$ That unique method called for a Constitution Revision Commission ("CRC") to meet ten years after the 1968 constitution was adopted and every twenty years thereafter to reconsider the entire constitution; determine what, if any, revisions the constitution needed; and propose revisions directly to the voting public. ${ }^{3}$ Two such revision commissions have met since 1968. ${ }^{4}$ A third will meet in 2017 and 2018. ${ }^{5}$ The twenty-year gaps, combined with Florida's steep population growth, ensure that the voters will be a substantially different group for each revision commission. The constitution and the voters will never be stepping into the same river twice. ${ }^{6}$

This Article provides a brief history of how the 1968 Florida Constitution came to be and considers some highlights of the revisions and attempted revisions to Florida's Constitution that have spanned the

* Mary E. Adkins is Master Legal Skills Professor and Director of Legal Writing and Appellate Advocacy at the University of Florida Fredric G. Levin College of Law in Gainesville, Florida. She wishes to thank Raymond C. Harrell, Jr. for his helpful essay on districting commissions titled "Rethinking Congressional and State Legislative Redistricting in Florida: The Pathway to Impartiality?" Raymond C. Harrell, Rethinking Congressional and State Legislative Redistricting in Florida: The Pathway to Impartiality? (unpublished essay 2016).

1 See Fla. CONST.

2 FLA. CONST, art. XI.

3 Id. $\S 2$.

4 Id.

5 Id.

6 See G.T.W. Patrick, The Fragments of the Work of Heraclitus of Ephesus ON NATURE 94 (1889). 
nearly fifty years since $1968 .^{7}$ Many issues have stayed alive the entire time. Some have not changed; some have changed flavor as time has progressed and the needs of Florida's people and land have changed. The Article begins in Part I with a brief overview of Florida's previous constitutions. $^{8}$ Part II discusses the societal, political, and legal forces that caused the 1968 constitution to be formed $;{ }^{9}$ Part III reviews some important procedural matters that faced the two CRCs that have met since $1968 ;^{10}$ and Part IV reviews some major issues that have persevered, in one form or another, for the entire span of nearly fifty years. $^{11}$ It does not, however, emphasize a comparison of the two CRCs, as that is a task which others have ably done. ${ }^{12}$ It also does not attempt to review the work of the two Taxation and Budget Reform Commissions that met in 1992 and 2008. The Taxation and Budget Reform Commission is now the fifth method by which the Florida Constitution may be amended. ${ }^{13}$ Instead, this Article takes a vertical perspective of the constitution, highlighting a few major issues that have arisen since the constitution was adopted in $1968 .{ }^{14}$ For the reader's convenience, this Article addresses the highlighted issues in the order in which the constitution is organized. This Article is intended to act as a historical guide to readers interested in current constitutional issues in Florida. As the much-quoted philosopher George Santayana has said, "Those who cannot remember the past are condemned to repeat it." 15 Perhaps Florida, with its growing and transient population, can escape this fate.

\footnotetext{
7 See infra Parts I-IV.

8 See infra Part I.

9 See infra Part II.

10 See infra Part III.

11 See infra Part IV.

12 See infra Parts I-IV. See, e.g., Rebecca Mae Salokar, Constitutional Revision in Florida: Planning, Politics, Policy, and Publicity, in STATE CONSTITUTIONS FOR THE TWENTY-FIRST CENTURY 19-57 (Tarr G. Alan \& Robert F. Williams eds., 2006) [hereinafter Constitutional Revision in Florida].

13 FLA. CONST. art. XI, § 6.

14 See infra Parts I-IV.

15 George Santayana, The Life of REASON 284 (1905).
} 


\section{Part I: Previous Constitutions of Florida}

The constitution currently governing Florida, adopted by voters in 1968 , is its sixth. ${ }^{16}$ Florida's first constitution was drafted in 1838 in the Panhandle town of St. Joseph when Florida was still a territory but anticipating statehood. ${ }^{17}$ Three years later, St. Joseph was decimated in a yellow fever epidemic; two years after that, a hurricane finished off what was left. ${ }^{18}$ Today's town of Port St. Joe was later founded two miles away. ${ }^{19}$

The second Florida Constitution was written in 1861, sixteen years after Florida attained statehood; its main purpose was to declare Florida's secession from the Union and identification with the Confederate States. ${ }^{20}$ The voters never adopted the third constitution written in 1865, and the fourth constitution, written in 1868 during Reconstruction, reflected the values of the Radical Republicans occupying Florida. $^{21}$ The 1868 constitution provided egalitarian education and voting provisions: it called for education for "all children residing within [Florida's] borders, without distinction or preference," and allowed all males at least twenty-one years of age and meeting citizenship and residency requirements to vote, regardless of "race, color, nationality, or previous condition." 22 However, as soon as Reconstruction ended and the Northern Radical Republicans left the former Confederate States to their own devices, Florida adopted another constitution, its fifth. ${ }^{23}$ That constitution, adopted in 1885, was a reaction to the Reconstruction constitution. ${ }^{24}$ It removed the language specifically allowing men of any race to vote, simply giving the franchise to "[e]very male person of the age of twenty-one years" and older; it called for segregated schools; and it banned mixed-race

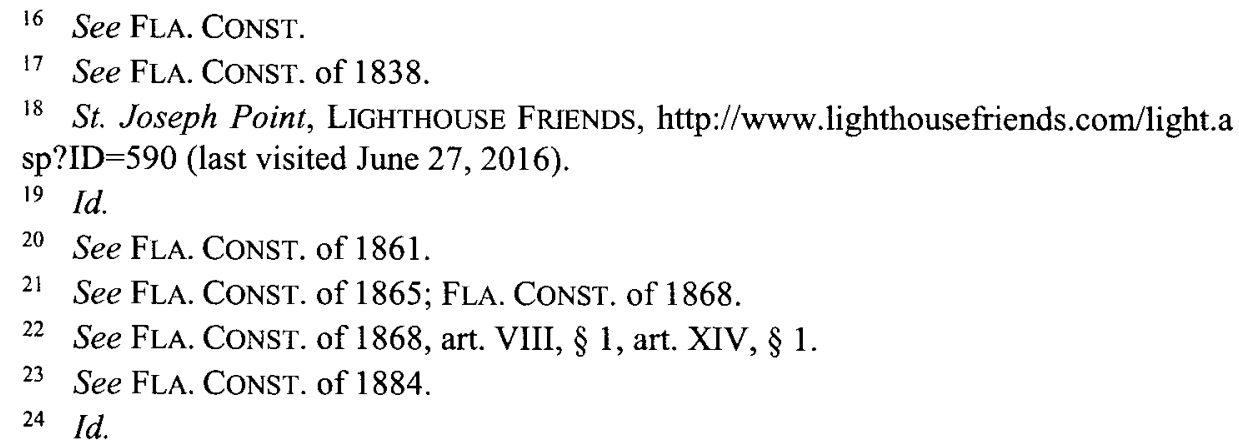


marriage. ${ }^{25}$ It provided for a convoluted court system and allowed counties to add to the courts as needed, leading to a system in which the types of courts and their jurisdictions varied from county to county and even from town to town, as municipal courts were also part of the mix. ${ }^{26}$ It contained curiously specific provisions better suited to statutes or even rules, such as the per mile reimbursement rate for legislators and the annual allotment of money for Florida Supreme Court library books. ${ }^{27}$ It called for the legislature to meet only sixty days every two years and forced local governments to apply to the legislature for anything but the most routine needs, thus ensuring that the sixty days of legislation every two years would be clogged with local bills. ${ }^{28}$

But years after the Radical Republicans left, Florida's citizens were soon faced with another radical challenge. The state's growth rate through the twentieth century can only be called radical. Between 1890 and 1960, Florida's population grew from 391,422 to $4,951,560 .^{29}$ Florida experienced population booms in the 1920s over land speculation; after World War II as veterans returned to the state that provided their subtropical training camps; and during the late 1950s to mid-1960s as the space race accelerated at and around Cape Canaveral on the east coast. ${ }^{30}$ As Florida's growth and scientific leadership became a symbol of modernity for the nation and world, Florida's constitution began to show its age. Florida's 1885 Constitution was worse than a relic of a horse-and-buggy age-it was a reflection of the anger that post-Reconstruction white segregationists felt after the loss of the Civil War and what they perceived as the oppression of Reconstruction. Florida's 1885 Constitution was an embarrassment for

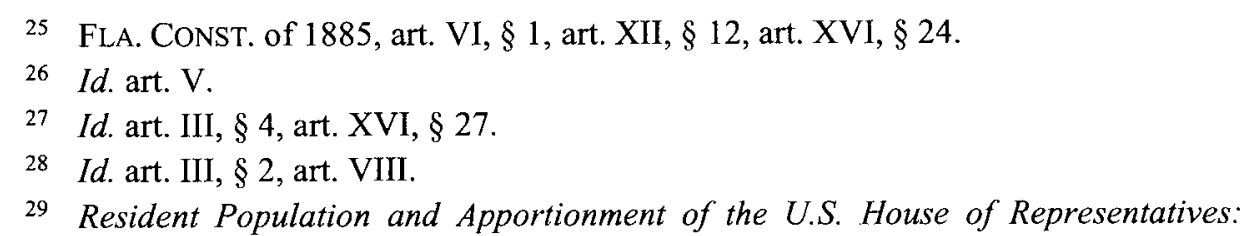

Florida, U.S. CENSUS BUREAU, http://www.census.gov/dmd/www/resapport/states/fl orida.pdf (last modified Dec. 28, 2000).

30 Compare Florida Census: 1910, EXPLORING FLORIDA, http://fcit.usf.edu/florida/ docs/c/census/1910.htm (last modified Feb. 1, 2005) (showing the population in Florida was around 750,000), with Florida Census: 1920, EXPLORING FLORIDA, http://fcit.usf.edu/florida/docs/c/census/1920.htm (last modified Feb. 1, 2005) (showing a large increase in Florida's population from 1910 to the 1920's, with about a 200,000 population increase). 
a swiftly modernizing and urbanizing state.

\section{PART II: Forces Forging A NeW CONSTITUTION FOR FLORIDA}

As a new generation of young men and women returned to Florida after World War II and the Korean conflict, they saw with fresh eyes the backward nature of Florida's political and legal system and they resolved to reform it. ${ }^{31}$ Kenneth H. "Buddy" MacKay, who would serve as a legislator, congressman, lieutenant governor, and, briefly, as governor after Lawton Chiles's sudden death, was one; MacKay stated that he and other reformers, such as Chesterfield Smith and LeRoy Collins, had been changed by their military experience and saw Florida "not as part of the Old South, but as part of the new America coming into being." 32

The reason that Florida's leadership remained backward-facing into the 1950s and 1960s, even though Florida itself was becoming more urban, ${ }^{33}$ was because its legislature had not substantially reapportioned since the $1920 \mathrm{~s}$, and the 1885 constitution made it hard to do so. ${ }^{34}$ Unfortunately, even though that constitution provided that the state reapportion every ten years, it limited the size of each House of the legislature, creating a situation in which a growing population would mean each legislator would represent more and more people, distancing citizens from their government. ${ }^{35}$ The House of Representatives provided that each county would have at least one representative but that no county could have more than three representatives (at the time, Florida had thirty-nine counties, not its current sixty-seven). ${ }^{36}$ While these limits may have made sense in 1885, when Dade County's population was counted only in the hundreds, ${ }^{37}$ once South Florida's

31 Buddy MacKay, How Florida Happened: The Political Education of Buddy MacKay 16 (University Press of Florida 2010).

32 Id.

33 Manning Dauer, Florida: The Different State, in REAPPORTIONMENT \& REPRESENTATION IN FLORIDA: A HistoriCAl COLLECTION 77-80 (MacManus, Susan A. ed., University of South Florida 1991).

34 See FLA. CONST. of 1885 , art. VII.

35 Id. $\S 3$.

36 Id.

37 Miami-Dade County, Florida, EXPLORING FLORIDA, http://fcit.usf.edu/florida/ 
population began to boom and North Florida's to stagnate, any trace of true representational fairness in Florida's legislature vanished. ${ }^{38}$

The result of the failure of Florida's legislative structures in the face of a rapidly growing population was a malapportioned legislature. The majority of the legislative districts remained in Northern Florida where the great majority of Florida's population resided in 1885, when the constitution had been written. ${ }^{39}$ The majority of people by the middle of the twentieth century, however, were in Central and Southern Florida, particularly the southeast coast, where the cities of West Palm Beach, Fort Lauderdale, and Miami, and their suburbs, were morphing into a megalopolis. ${ }^{40}$ By July 1961, Florida's least populous senate district had only $1 \%$ of the population of the smallest senate district and only $12.3 \%$ of the population could elect a majority. ${ }^{41}$ In the House, the least populous district had only $0.9 \%$ of the population of the largest, and $14.7 \%$ of the population could elect a majority. ${ }^{42}$

The effect of this malapportionment was that Florida's legislature focused insufficiently on the modern urban needs of the population centers and concentrated instead on resisting giving encouragement to the cities. This phenomenon manifested itself in Florida's tax structure, among other ways. For example, the legislature tolerated betting on horse racing, which was popular in populous South Florida, but its tax revenues were distributed evenly to each county. ${ }^{43}$ That way, if sinful Hialeah, in the south, wanted to profit from gambling, tiny Gadsden County and Baker County, in the north, would

docs/c/census/Miami-Dade.htm (last modified Feb. 1, 2005).

38 See generally Florida Census Data, EXPLORING FLORIDA, http://fcit.usf.edu/flori $\mathrm{da} / \mathrm{docs} / \mathrm{c} /$ census.htm (last visited May 30, 2016) (showing the Florida census by county).

39 See generally id. (showing the Florida census by county and every ten decades from 1840-1980).

40 See generally Florida Census: 1950, EXPLORING FLORIDA, http://fcit.usf.edu/ florida/docs/c/census/1950.htm (last visited July 25, 2016) (showing the population of Palm Beach, Broward, and Miami-Dade County, where each city is located during 1950).

41 ADVISORY COMM'N ON INTERGOVERNMENTAL RELATIONS, A COMMISSION REPORT: APPORTIONMENT OF STATE LEGISLATURES, at A-7 (Dec. 1962).

42 Id.

43 FLA. CONST. of 1885 , art. IX. 
benefit disproportionately from it.

The legislators who occupied the superabundance of legislative seats awarded to rural counties became known as the Pork Chop Gang. ${ }^{44}$ Although this moniker came from an urban newspaper editor, many of the Gang members embraced the title. ${ }^{45}$ In fact, the legislators from small counties agreed to vote together to preserve what they saw as the "Southern way of life," which, they perceived, was threatened by the rapid population rise they saw to their south. ${ }^{46}$ The power the Pork Choppers had was not just in their numbers: under the 1885 constitution, legislators had the power to grant or deny requests for any local matter that was not routine. ${ }^{47}$

The first sustained threat to the reign of the Pork Chop Gang was LeRoy Collins, who was governor from 1955 to $1961 .{ }^{48}$ Collins, though from Tallahassee in the north of Florida, saw the inequity in the legislature and attempted several times to force the legislature to effect a meaningful reapportionment. ${ }^{49}$ However, the legislators had a problem: to draw the legislative district lines so that each district would contain approximately the same number of people would mean that most of them would be out of the legislature. ${ }^{50}$ Most of the seats in a fairly drawn Florida legislature would be in the central and southern parts of the state. ${ }^{51}$ Only a few would remain for the northern legislators to share. ${ }^{52}$ For them, the meaning of a meaningful reapportionment was loss of power. Therefore, they resisted Collins's efforts, and finally, they outlasted him. ${ }^{53}$ When LeRoy Collins left the

\footnotetext{
44 Robert Sherrill, Florida's Legislature: The Pork Chop State of Mind, HARPER's, Nov. 1965, at 82-97.

45 Id.

46 Id.

47 See Fla. CONST. of 1885, art. VIII.

48 Governor Thomas LeRoy Collins, LEON FLORIDA's CAPITAL COUNTY, http://cms. leoncountyfl.gov/Library/LibraryInformation/About-LeRoy-Collins (last visited July $25,2016)$.

49 See id.

50 See supra notes 38-42 and accompanying text.

51 Id.

52 Id.

53 Id.
} 
governor's office in early $1961,{ }^{54}$ the Pork Chop Gang remained as strong as ever.

Another problem made equitably redrawing district lines difficult. The 1885 constitution limited the number of seats in the legislature. ${ }^{55}$ Florida's population in 1960 was $4,951,560$-more than twelve times the population in $1890 .{ }^{56}$ Restricting the size of the House to sixty-eight seats was too inflexible a structure for a state that showed every sign of continuing growth and change. And it was not only the population that was changing in Florida: the state was the site of the burgeoning space program. ${ }^{57}$ Soon, Cape Canaveral would draw the eyes of the world as it raced to create a spaceship capable of taking human beings to the moon. A backward-facing government would not help Florida's ability to function in the twentieth century, much less the twenty-first century, which was coming ever nearer.

But to change the number of seats in the legislature, to give it wiggle room, meant amending the constitution. And the constitution itself provided that amendments could be proposed and placed on the ballot for popular adoption only by the legislature and only one section at a time. ${ }^{58}$ Practically speaking, this meant that, even if the legislature was inclined to amend the constitution in an attempt to modernize it, the legislature would have to propose free-standing amendments rather than propose a cohesive group. In fact, one proposed extensive revision to the constitution in 1958 was invalidated by the Florida Supreme Court because it violated the single-section restriction in the existing constitution. ${ }^{59}$ Any change to the constitution would have to come incrementally, if at all.

By the early 1960s, though, two forces were beginning to apply new pressure to the legislature and to the other infirmities of the 1885

\footnotetext{
54 Governor Thomas LeRoy Collins, supra note 48.

55 MARy AdKINS, MAKING MOdern Florida: How THE SPIRIT OF REFORM SHAPED A NEW STATE CONSTITUTION 55 (2016).

56 Florida Census Data, supra note 38.

57 Kennedy Space Ctr., Kennedy Space Center Story, NASA, https:/www.nasa.gov/ centers/kennedy/about/history/story/ch18.html (last updated Feb. 24, 2008).

58 FLA. CONST. of 1885 , art. XVII, $\$ 1$.

59 Rivera-Cruz v. Gray, 104 So. 2d 501, 505 (Fla. 1958).
} 
constitution. One force was the new generation of emerging leaders, which included Buddy MacKay and LeRoy Collins were part; the other was the federal courts. ${ }^{60}$ Alone, Florida's new reformers remained thwarted by the Pork Chop Gang. But with the federal courts, including the Supreme Court, weighing in on state apportionment, the hard hide of the Pork Chop Gang began to soften up. ${ }^{61}$

This Article will briefly discuss the series of Supreme Court cases that finally moved Florida and other states into the twentieth century. ${ }^{62}$ The first, Baker v. Carr,${ }^{63}$ decided in 1962, allowed federal courts to involve themselves in state legislative districting. ${ }^{64}$ The decision had the effect of nudging a boulder that already lies on a steep slope: it seemed not to do much on its own, but once set into motion it gained speed and force. After Baker v. Carr, many state reapportionment cases were filed in federal district courts throughout the nation, including one in the Southern District of Florida. ${ }^{65}$ In 1964, the U.S. Supreme Court decided six more cases, which are known as the Reynolds $v$. Sims cases. ${ }^{66}$ This group of cases mandated that state legislatures must be drawn to meet a one-person, one-vote standard. ${ }^{67}$ One week after the Reynolds group of cases was decided, the Court decided another nine cases, including the Florida case Swann $v$. Adams. ${ }^{68}$ The Court remanded Swann with instructions to the district court to review in light of the Reynolds one-person, one-vote standard ${ }^{69}$

This turned out to be only the first of three rounds the Swann reapportionment case took to the Supreme Court. ${ }^{70}$ These

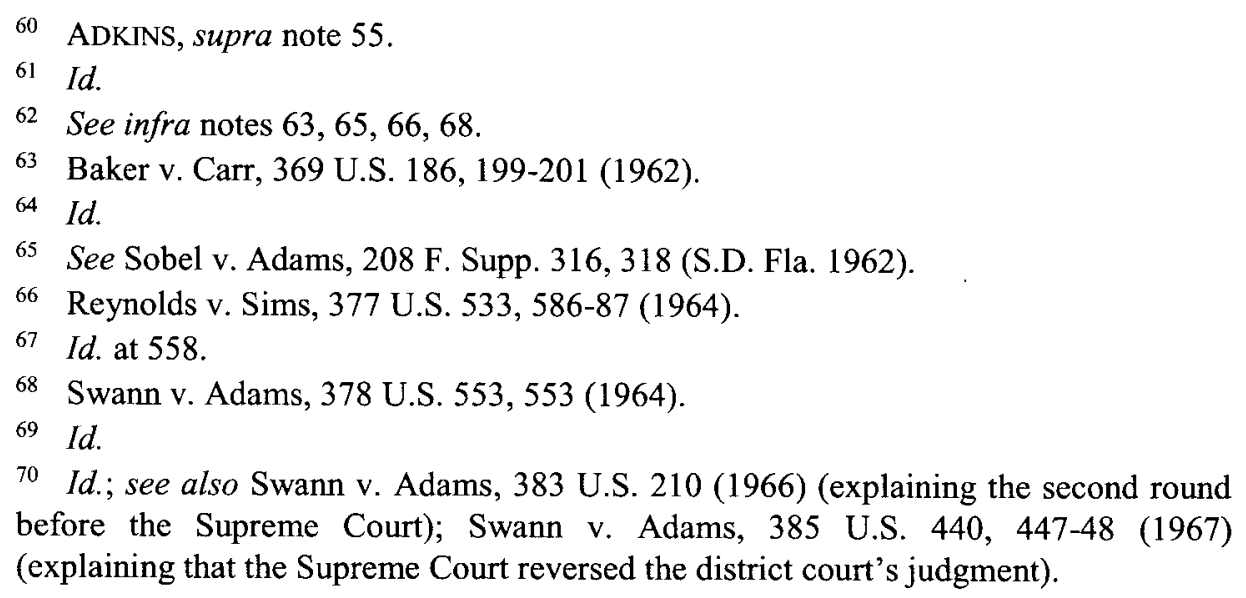


reapportionment decisions forced the Florida Legislature to begin to make the painful changes that were necessary to represent the citizens fairly.

As the legislature reluctantly crept closer to a fair apportionment, and the Pork Chop Gang began to loosen its grip, some legislators were able to successfully propose a joint resolution for a constitutional amendment that would allow revision of the entire constitution. ${ }^{71}$ That amendment passed in $1964 .^{72}$ The stage was thus set for the next step: a bill, passed in the 1965 session, creating a Constitution Revision Commission. ${ }^{73}$

The Constitution Revision Commission Bill provided that the governor, speaker of the House of Representatives, president of the Senate, chief justice of the Supreme Court, and president of the Florida Bar each would appoint commissioners; one of the governor's appointments would be the chair. ${ }^{74}$ The attorney general was the only person who was automatically a member. ${ }^{75}$ The commissioners were appointed in late 1965, and the CRC began its work formally on January 11, 1966, with Bartow attorney Chesterfield Smith as chair. ${ }^{76}$ The CRC was charged with meeting "as soon as practical" after the bill became law, with holding public hearings, and with requesting recommendations from the governor, cabinet, legislature, and supreme court, all of which were directed to "aid and assist" the CRC. ${ }^{77}$ Finally, the CRC was to submit its "report and recommendations" to the legislature at least sixty days before the legislature's 1967 regular session. ${ }^{78}$ Its budget of $\$ 100,000$ was intended to employ staff and

\footnotetext{
71 ADKINS, supra note 55.

72 Marsha Hosack \& P.K. Jameson, Citizens Initiatives in Florida: An Analysis of Florida's Constitutional Initiative Process, Issues, and Alternatives, 23 FLA. ST. U. L. REV. 417, 423-24 (1995) (discussing how 1964 voters approved an amendment allowing revision to the constitution without holding a constitutional convention).

73 ADKINS, supra note 55.

74 Id. at 56.

75 Id.

76 Id. at 62,75 .

77 Id. at 56

78 Id. at 57.
} 
cover the travel expenses of each commissioner for a year. ${ }^{79}$

Smith divided the CRC into eight subject matter committees and two governing committees. ${ }^{80}$ The subject matter committees were Education and Welfare; Executive; Human Rights; Judicial; Legislative; Local Government; State Finance; and Suffrage and Elections. ${ }^{81}$ The governing committees were Steering and Rules, which Smith chaired; and Style and Drafting. ${ }^{82}$

The CRC spent a year creating its product, meeting both as a whole and in committees. ${ }^{83}$ The first major task Smith required of each subject matter committee was to formulate what he called "certified questions" that the CRC as a whole would debate. ${ }^{84}$ These were to be "broad, philosophical questions" about issues that might be in the constitution. ${ }^{85}$ The committees met through the late-winter weeks. ${ }^{86}$ In two days in March and April, the CRC met as a whole to debate the eighteen questions the committees had produced. ${ }^{87}$ At the March and April plenary meetings, Smith assigned CRC members to debate the pros and cons of each certified question. ${ }^{88}$ The debate of these certified questions ensured that seemingly uncontroversial issues would have the benefit of the open discussion. ${ }^{89}$ Smith then assigned each committee to meet again, armed with the knowledge gleaned from the certified question discussions, to draft the section of the constitution he had previously charged them with reviewing. ${ }^{90}$ No committee saw the work of any other committee until a separate three-person Style and Drafting

79 Id

80 Id. at 75.

81 Id.

82 Transcript, Jan. 11, 1966, Fla. St. Archives, Record Group 1006, Series 720, Box 1, Folder 9; Rule 24, Florida Constitution Revision Commission, Fla. St. Archives, Record Group 1006, Series 720, Box 3, Folder 3 [Fla. Transcript Archives].

83 Id.

84 Index, Mar. 25, 1966, Fla. St. Archives, Record Group 1006, Series 720, Box 1, Folder 7 [Fla. Index].

85 Id.

86 Id.

$87 \mathrm{Id}$

88 Id.

$89 \quad I d$.

90 Id. 
Committee knitted the parts together. ${ }^{91}$

That first draft of the proposed new constitution was published in newspapers all over the state in late June 1966; then, in July, the CRC held public hearings in five cities throughout the state, inviting comments on the draft. ${ }^{92}$ It was at these hearings that interest groups could have a say, and many, such as the county tax assessors' organization and the League of Women Voters, attended each public hearing. ${ }^{93}$

Based on the comments gathered at the public hearings, the CRC committees met again throughout the fall to modify and polish their respective sections of the constitution. ${ }^{94}$. This time, the separate parts were published to the CRC members themselves as a final draft before the final plenary meeting. ${ }^{95}$ Members were invited to suggest changes to the draft and would have the opportunity to debate the proposed amendments at the final meeting. ${ }^{96}$

The CRC met as a whole for the final time in a three-week session that lasted from just after the Thanksgiving weekend in November 1966 until mid-December. Commissioners proposed nearly two hundred amendments to their draft. ${ }^{97}$ Some represented minority positions that individual CRC members were trying, once again, to push through the entire CRC after losing at the committee level. ${ }^{98}$ Others represented ideas for parts of the constitution other than those the

\footnotetext{
$91 \quad$ Id.

92 Id.

93 See generally The Fla. Bar, Overview of Florida's Constitution Revision Commission, FLA. B., https://www.floridabar.org/cmdocs/bs 100.nsf/c5aca7f8c251a 58d85257236004a107f/a1fa14fb2f80ed1685257eac0063567f/\$FILE/Constitution\%20 Revision\%20Commission\%20Overview.pdf (last visited July 25, 2016) (explaining that interested groups attend public hearings and submit proposals).

94 Id.

95 Id.

96 Rule 1.6, Florida Constitution Revision Commission, Fla. St. Archives, Record Group 1006, Series 720, Box 3, Folder 6 [hereinafter Rule 1.6].

97 List of Amendments, Fla. St. Archives, Record Group 1006, Series 723, Box 1, Folder 1 [hereinafter Amendments].

98 Id.
} 
proposing commissioner had served on. ${ }^{99}$ The judicial article, however, had the dubious honor of having more proposed amendments to it than any other part of the proposed constitution-perhaps to be expected in a CRC dominated by lawyers. ${ }^{100}$ At the end of the three weeks, the group had combed through the entire proposed constitution three times. ${ }^{101}$ Thirty-six commissioners went home; Style and Drafting Chair Hugh Taylor stayed to finish the drafting process. ${ }^{102}$

The CRC's work may have been done at this point, but the constitution still had a major hurdle to leap: the Florida legislature. The statute forming the CRC had kept a safety valve for the legislature-it required the CRC to present its draft to the legislature, which then had the power to approve, reject, change, or ignore it. ${ }^{103}$ Perhaps the 1965 legislature had passed the CRC-creating bill so easily because this feature kept any new constitution within its control. However, a series of unexpected events ensured the legislature would be kept off-balance as it began its deliberations.

First, only a few weeks before the CRC had begun its final session, Florida had done something it had never done since Reconstruction: it elected a Republican governor, Claude Kirk. ${ }^{104}$ Kirk had spent much of his transition time watching the entire three weeks of $\mathrm{CRC}$ debates and decided to make the constitution the first item of business for his gubernatorial term. ${ }^{105}$ So, in his inauguration speech, he called for a surprise special session of the legislature to begin in less than a week. Its purpose: to work on the proposed constitution. ${ }^{106}$

In the same election that brought Kirk into office, a new legislative apportionment scheme had brought many new faces into the

\footnotetext{
99 Id

100 Id.

101 Id.

102 Hank Drane, Miscellaneous, FLA. TIMES-UniON, Dec. 18, 1966.

103 Fla. Stat. Ch. 65-561.

104 Journal of the 1997-1998 Constitution Revision Commission: Number 1Organization Session, 12-13 (June 16, 1997), http://fall.fsulawrc.com/crc/pdf/crc1.pdf. 105 Interview with Claude Kirk, Governor of Fla., in Gainesville, Fla. (Dec. 16, 1986).

106 Governor Claude Kirk Inauguration (1967), YouTUBE (May 31, 2016), https://www.youtube.com/watch?v=7GSip8DSVlY.
} 
legislature. The newest apportionment plan, though not perfect, brought Florida closer to a one-person, one-vote standard than any apportionment plan had before. ${ }^{107}$ The new legislators were younger, more urban, and more Republican than in any previous Florida legislature. ${ }^{108}$ This was the first session of the legislature in which the Pork Chop Gang did not hold power. ${ }^{109}$ It was this fresh group who returned to Tallahassee on January 9, 1967, to review the draft of the proposed constitution. ${ }^{110}$

As this group of new legislators sat down for their new governor's special session to review their new proposed constitution, the final unexpected event happened: at noon that day, the U.S. Supreme Court ruled the latest apportionment plan unconstitutional. ${ }^{11}$ All the new legislators were now not legislators. They had no authority to consider the new constitution. They in fact could do nothing, not even plan how to reapportion themselves. Not until a month later did the U.S. District Court for the Southern District of Florida, the trial court to which the U.S. Supreme Court had remanded the case, announce a new apportionment plan. ${ }^{12}$ Only then could legislators run again for election in their new districts.

That hiccup in the passage of the new constitution ultimately meant that the legislature would not turn its attention to the new constitution for more than a year. Four special sessions later, on July 4, 1968 , the legislature finally and triumphantly announced it had agreed on a new constitution to place on the November ballot. ${ }^{113}$ There was one hole in the constitution, however: the judicial article, which had

\footnotetext{
107 See generally Allen Morris et AL., The Florida HandBook 274 (34th ed. 2014) (explaining the reapportionment process in Florida and the shift towards a Republican legislature).

108 See generally id. at 264 (discussing changes in the make-up of the legislature).

$109 \quad I d$

110 See generally id. at 255 (discussing the increased amount of younger legislators returning to office between 1966 and 1967).

111 See Swann v. Adams, 385 U.S. 440, 447-48 (1967) (ruling the latest apportionment plan unconstitutional).

112 See Swann v. Adams, 263 F. Supp. 225, 225-28 (S.D. Fla. 1967) (announcing a new apportionment plan).

113 Hank Drane \& Everette Williard, New Constitution Approved, FlA. TIMESUNION, July 4, 1968.
} 
been the target of so many proposed amendments by the CRC, was not on the ballot. ${ }^{114}$ It was the only article of the proposed constitution on which the House and Senate could not agree. ${ }^{115}$

In November 1968, the people of Florida voted to adopt this nearly complete new constitution, and it took effect in January 1969. ${ }^{116}$ It contained some features that were new at the time but that Floridians now take for granted. In the legislative article, it called for a legislature that meets every year instead of every two years; a flexible numbers of legislators, to allow for growth or redistricting as needed; and a review by the Florida Supreme Court in the event the legislature could not agree on a legislative scheme. ${ }^{117}$ The latter provision would avoid the pain of having redistricting imposed by federal courts rather than by state officials. The new declaration of rights forbade discrimination on the basis of race, and the education article lacked language by which anyone could claim schools could remain segregated. ${ }^{18}$ The office of lieutenant governor was new, and for the first time a governor could serve two full terms. ${ }^{19}$ Local governments had the option of ruling themselves rather than having to request all but the most mundane functions from legislators. ${ }^{120}$

The 1968 constitution also provided for many ways to be amended. Rather than restricting the power to amend the constitution to the legislature, as the 1885 constitution had, the 1968 constitution provided for four ways to amend it: by legislative joint resolution; by convention; by citizens' initiative; and by an automatically recurring revision commission. ${ }^{121}$ This recurring CRC would meet ten years after the constitution was adopted and every twenty years thereafter. ${ }^{122}$ The

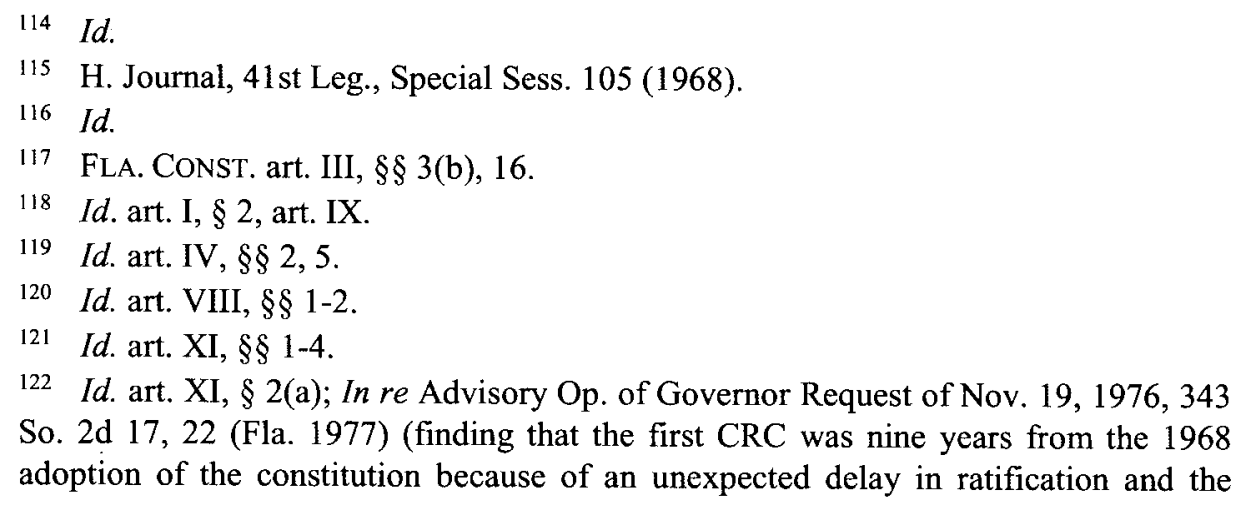


automatically occurring commission was then, and remains, a feature unique in state constitutions. No other state has included a provision like this one, although it has caught the eye of scholars. ${ }^{123}$ The recurring $\mathrm{CRC}$ has survived more than one attempt to abolish it. ${ }^{124}$

Before it was time for the first recurring $\mathrm{CRC}$, however, the legislature succeeded in passing the judicial article, article $\mathrm{V}$ of the 1968 constitution, to make that constitution revision complete. ${ }^{125} \mathrm{~A}$ proposed article V appeared on the 1970 ballot, but voters rejected it. ${ }^{126}$ A successful article V emerged for the 1972 ballot. ${ }^{127}$ It emerged under the leadership of Talbot "Sandy" D'Alemberte in the House and Dempsey Barron in the Senate. ${ }^{128}$ That judicial article transformed the confusing hodgepodge of courts, judges, magistrates, constables, and justices of the peace - a mix that differed from county to county-into the simpler, more streamlined system now in place. ${ }^{129}$ The article provided for just four levels of court: county court, circuit court, district court of appeal, and supreme court. ${ }^{130}$ The county and circuit courts are trial courts; the district courts of appeal and supreme court are appellate courts. ${ }^{131}$ The circuit courts have a dual role, as they also serve as the

failure to adjust language to account for that delay).

123 FLA. ConST. art. XI, § 2; Constitutional Revision in Florida, supra note 12, at 22; see generally Robert F. Williams, Are State Constitutional Conventions Things of the Past? The Increasing Role of the Constitutional Commission in State Constitutional Change, 1 HOFSTRA L. \& POL'Y SYMP. 1, 1-26 (1996) (discussing scholar opinions on the role of the CRC).

124 Talbot D'Alemberte, The Florida State Constitution: A Reference GUIDE 147 (Westport, Conn: Greenwood Press 1991); see generally Joseph W. Little, The Need to Revise the Florida Constitutional Revision Commission, 52 FLA. L. REV. 475, 475-95 (2000) (discussing multiple CRC rejections); Mary Ellen Klas, Negron gets support for plan to abolish constitutional commissions, TAMPA BAY TIMES (Feb. 9 , 2012), http://www.tampabay.com/blogs/the-buzz-florida-politics/content/negrongets-support-plan-abolish-constitutional-commissions [hereinafter Negron get support].

125 Little, supra note 124 , at 476 n.8.

126 See generally FLA. CONST. of 1972, art. V (1971) (showing Article V was voted on in 1972 subsequent to the 1970 vote).

127 Id.

128 Id.

129 See generally id. art. V (explaining the system).

130 Id. art. $\mathrm{V}, \S 1$.

131 Id. $\S \S 3-6$. 
first-level appellate court for the county courts. ${ }^{132}$ The jurisdictions are constitutionally defined. ${ }^{133}$ Judicial terms, qualifications, and methods of selection or election are constitutionally provided, and other units of government may not create other types of judges. ${ }^{134}$

With so many methods of amendment, it was predictable that Florida's 1968 Constitution would undergo many changes. Certain issues have recurred in the last fifty years of constitution revision, including issues recurring in the two revision commissions that have met to date. The remainder of this Article identifies and explores some of those issues in an attempt to inform citizens interested in the next $\mathrm{CRC}$, which will convene in the late winter of $2017 .{ }^{135}$

\section{Part III: Procedural Matters for Constitution Revision COMMISSIONS}

\section{A. Step One: Ten Years After What?}

In early 1976, Chesterfield Smith, the 1966 CRC chair, and Judge Thomas Barkdull, a member of that CRC's Steering and Rules Committee, met with Governor Reubin Askew, Senate President Dempsey Barron, and House Speaker Don Tucker. ${ }^{136}$ The pair recommended to each of them that they appoint a committee to plan for the upcoming CRC. ${ }^{137}$ Smith and Barkdull also alerted the three CRC appointers to an anomaly in the new constitution: it required the first revision commission to be established "[w]ithin thirty days after the adjournment of the regular session of the legislature convened in the tenth year following that in which this constitution is adopted," but it also required it to submit any changes it recommended "not later than one hundred eighty days prior to the next general election." 138 Because the constitution was adopted in 1968, it should have been established after the 1978 legislature adjourned, which was in June of 1978, as the

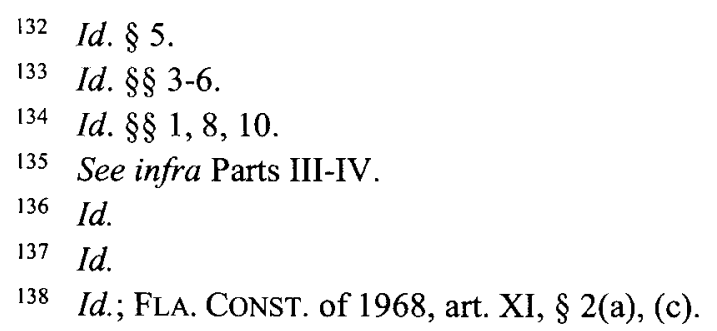


legislature convened on the first Tuesday in April 1978 and met for sixty days. ${ }^{139}$ However, the next general election would be in November 1978, and 180 days before that would be May $1978 .{ }^{140}$ Therefore, the constitution called for the CRC to submit its recommendations before it convened. The problem may have sprung from the fact that the 1966 CRC had drafted the language in 1966, expecting the legislature to pass the constitution to the people for ratification in 1967. A memo directed to Lieutenant Governor J.H. Williams, however, stated that 1966 Style and Drafting Chair Hugh Taylor said the language may have been "drafted at a time when people were thinking of biennial legislative sessions" and actually contemplated a 1979 session and a 1980 ballot. ${ }^{141}$

A CRC established in 1979 would have about a year, depending on exact dates of the 1979 legislative session, to examine the constitution and determine what, if any, changes needed to be made, and still be able to submit its recommendations before the required 180 days before the next regular election; similarly, a CRC established ten years after a 1967 election would have a similar period of time before a 1978 election. But, for a variety of reasons, the legislature had required eighteen months and four sessions before agreeing on the text of the new constitution, and as a result, the document did not reach the ballot until November $1968 .{ }^{142}$ The version that was adopted by popular vote in the November 1968 election retained the ten-year language, creating the conundrum that confronted constitution watchers in $1976 .{ }^{143}$

This conundrum resulted in Governor Reubin Askew, who had served on the $1966 \mathrm{CRC}$, asking the Florida Supreme Court in November 1976 for an advisory opinion to determine which provision

\footnotetext{
139 H. Journal, 5th Leg., 2d Sess. (1978); H. Journal, Reg. Sess. (1978).

$140 I d$.

141 Supplemental Memorandum from David V. Kerns to Lt. Gov. J.H. Williams, Jul. $20,1976$.

142 See The Fla. Bar, Florida Constitutional Revision, FLA. B., https://www.florida bar.org/divcom/pi/bips2001.nsf/1119bd38ae090a748525676f0053b606/ebe1c07f62c2 bb5d8525669e004f7c74! OpenDocument (last updated May 26, 2005).

143 See Billy Buzzett \& Steven J. Uhlfelder, Constitution Revision Commission: A Retrospective and Prospective Sketch, FLA. B. J. 22, 22 (1997) [hereinafter $A$ Retrospective and Prospective Sketch].
} 
would prevail. ${ }^{144}$ To put it bluntly, the Florida Supreme Court would have to determine which provision to ignore. In February 1977 it ruled that the ballot date was the most important: the proposed revisions should go on the ballot ten years after the constitution's adoption, the 1978 election. ${ }^{145}$ This decision cleared the way for the governor, chief justice, and legislative leaders to begin to decide whom to appoint for a commission that would begin meeting that year. Because the 1977 legislative session would close in early June, the appointing authorities had about four months from the date of the supreme court's decision to meet the deadline of appointing their respective members within thirty days of the close of the 1977 regular legislative session, as the constitution provided. ${ }^{146}$

Jockeying, speculation, and games soon began. Would Governor Askew, who had served on the previous commission, appoint himself to this commission? Would he, as some suspected, appoint himself chair? Who would appoint the nine seats for the House of Representatives - its current speaker, or his successor? Hundreds of people applied to the various appointing authorities hoping to serve.

Governor Askew, who had the authority to appoint the chair, chose Sandy D'Alemberte, who had worked so effectively to pass the new article $\mathrm{V}$ five years earlier. ${ }^{147}$ There was no time to spare. The $\mathrm{CRC}$ had little time to plan and had to spend much of the time in its initial meetings debating rules. ${ }^{148}$

\section{B. Initial Organization}

Planning for the $\mathrm{CRCs}^{149}$ has become progressively more

144 See In re Advisory Op. of Governor Request of Nov. 19, 1976, 343 So. 2d 17, 18 (Fla. 1977).

145 Id. at 24.

146 FLA. CONST. art. XI, § 2(a).

147 Steve Bousquet, At 80, Florida icon Sandy D'Alemberte marks a milestone, TAMPA BAY TIMES (May 30, 2013), http://www.tampabay.com/blogs/the-buzzflorida-politics/at-80-florida-icon-sandy-dalemberte-marks-a-milestone/2123954.

148 See generally Billy Buzzett \& W. Dexter Douglass, Constitution Revision Commission: Planning the Process, FLA. B. J. 16, 17 (1997) (showing there was timeconsuming debate) [hereinafter Planning the Process].

149 See generally Rebecca Mae Salokar, Constitutional Politics in Florida: Pregnant 
organized. The 1966 organizational meeting took place on a 1965 University of Florida football game weekend, at which Chesterfield Smith, the 1966 CRC chair, and several newly appointed CRC members made initial rules and set out a rough schedule. ${ }^{150}$ Third District Court of Appeal Judge Thomas Barkdull, who attended that meeting, recalled that the group of Gator planners became the Steering and Rules Committee for that CRC. ${ }^{151}$

Although Askew, Barron, and Tucker had appointed a planning committee for the 1977-78 CRC, the commissioners themselves had little time to plan. ${ }^{152}$ D'Alemberte did appoint an executive director, Tallahassee lawyer Steven Uhlfelder, to handle organizational and administrative details and to manage that CRC's one million dollar budget. $^{153}$ But the CRC had to formulate its own rules, as the constitution provides, ${ }^{154}$ and doing so took time. One of the key decisions the 1977-78 CRC had to make was whether to require a supermajority to place proposals on the ballot for public adoption. ${ }^{155}$ After much debate, they decided a simple majority would suffice. ${ }^{156}$ This decision would affect the success of that CRC's proposals at the ballot.

Determined to see a smooth process for the next CRC, Governor Lawton Chiles formed, by executive order in June 1996, a steering committee for it. ${ }^{157}$ The steering committee consisted of a representative of each of the appointing authorities and of the Attorney

Sows or Deliberative Revision 2 (Fla. Int'1 Univ. Dep't of Political Sci. 2001) [hereinafter Constitutional Politics in Florida]. Some refer to the $1966 \mathrm{CRC}$ as the SRC, Statutory Revision Commission, because it was created by statute rather than by constitutional provision. Id.

150 Interview with Hon. Thomas H. Barkdull, Third District Court of Appeals (Dec. $16,1986)$.

151 Id.

152 See Fla. Legis. Research Ctr., Our Florida Legacy, FLRCM, http://www.flrcm.g ov/UserContent/docs/Files/book_sample.pdf (last visited June 26, 2016).

153 Constitutional Revision in Florida, supra note 12, at 30.

154 FLA. CONST. art. XI, § 2(c).

155 See generally A Retrospective and Prospective Sketch, supra note 143, at 23 (explaining the similarities between the 1977 and 1997 commissions).

156 Interview with Barnett and D'Alemberte (Apr. 29, 2014).

157 Constitutional Revision in Floridas, supra note 12, at 30-33. 
General's office. ${ }^{158}$ While Attorney General Bob Butterworth, Senate President Jim Scott, and House Speaker Peter Rudy Wallace attended most steering committee meetings themselves, Chief Justice Gerald Kogan appointed Judge Barkdull, who had served on both of the previous CRCs, as his designate, and Lawton Chiles's general counsel, Dexter Douglass, served as Chiles's proxy and as the steering committee chair. ${ }^{159}$ That committee drafted rules for the CRC; hired an executive director, general counsel, and other attorneys as staff; created a budget for the legislature to pass; and created a schedule of meetings and public hearings. ${ }^{160}$ One of the rules the steering committee drafted was to require a supermajority of twenty-two votes for proposals to go on the ballot. ${ }^{161}$ The committee had seen that the simple-majority rule of twenty years earlier had resulted in too many proposals going on the ballot and in many of those proposals not having broad enough support to gain a majority of votes at the polls. ${ }^{162}$ Also, because the party affiliation of the appointing parties suggested the CRC members would be split evenly between Democrats and Republicans, the steering committee reasoned that requiring a supermajority would ensure broad support across parties for each proposal. ${ }^{163}$

\section{Selecting Commissioners}

The Florida Constitution specifies that each CRC shall be composed of thirty-seven members. ${ }^{164}$ Any person can be appointed as a commissioner: there are no restrictions. ${ }^{165}$ The governor selects fifteen members, about $40 \%$ of the CRC; the Speaker of the House selects nine members and the President of the Senate selects nine members, giving the legislative branch about $49 \%$ of the CRC; the Chief Justice of the Florida Supreme Court selects three members, or about $8 \%$; and the attorney general is automatically a member of each

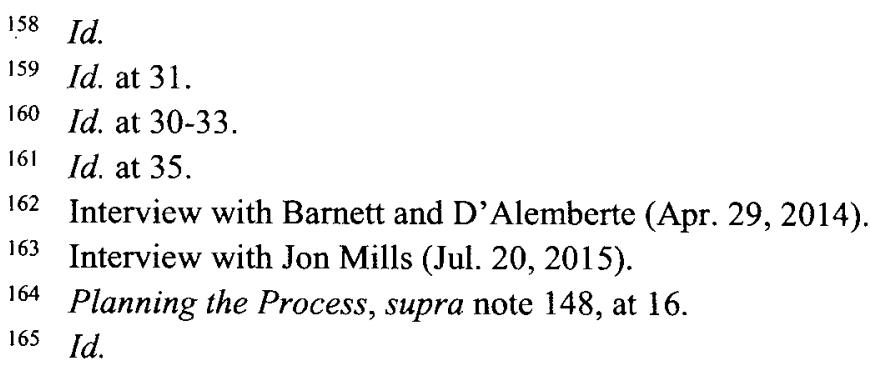


CRC. ${ }^{166}$ A 1998 amendment proposed by the CRC and adopted by the voters changed the period for appointing commissioners from thirty days after the regular legislative session ends to thirty days before it begins. ${ }^{167}$ Thus, the $2017-18 \mathrm{CRC}$ will have more time to complete its work than the previous two commissions had. ${ }^{168}$

All of the 2017 appointers are now known. ${ }^{169}$ When Rick Scott and Pam Bondi were reelected as governor and attorney general, respectively, in November 2014, Bondi became the attorney general who would be the only automatic CRC member in the 2017-18 cycle, and Scott became the governor who would appoint fifteen members. ${ }^{170}$ In September 2015, the House of Representatives selected Richard Corcoran, of Land O' Lakes, as speaker-designate. ${ }^{171}$ Corcoran will become Speaker in November 2016 barring the unlikely event of a change in the majority party in the House; Corcoran will appoint nine members. ${ }^{172}$ In November 2015, the Senate determined that Joe Negron, of Stuart, will be its President and will take office in November 2016, again barring a change in majority in the Senate; Negron will appoint nine members. ${ }^{173}$ And early in February, the Florida Supreme Court announced that Jorge Labarga will succeed himself as Chief Justice, the first Chief to succeed himself since $1865 .{ }^{174}$ However, the

166 FLA. ConST. art. XI, $\S 2$ (a); Planning the Process, supra note 148, at 16.
167 Planning the Process, supra note 148, at 16.
168 Id.
169 Kristen M. Clark, Education effort underway before next Florida Constitution Revision Commission in 2017-18, MIAMI HERALD, (Oct. 27, 2015), http://miami herald.typepad.com/nakedpolitics/2015/10/education-effort-underway-before-next-

florida-constitution-revision-commission.html.

170 Id.

171 Mary Ellen Klas, With stinging critique of Florida House, Corcoran faces pushback, MIAMI HERALD, (Sept. 19, 2015), http://www.miamiherald.com/news/po litics-government/state-politics/article35867703.html [hereinafter With stinging critique].

172 Id.

173 Steve Bousquet, Next Florida Senate President Joe Negron promises improved universities, TAMPA BAY TIMES (Dec. 2, 2015), http://www.tampabay.com/news/poli tics/stateroundup/next-florida-senate-president-joe-negron-promises-improveduniversities $/ 2256200$.

174. Kristen M. Clark, Jorge Labarga to serve rare 2nd term as chief justice of Florida Supreme Court, MIAMI HERALD, (Feb. 2, 2016), http://www.miamiherald.com/ 
Chief Justice appoints only three members and is the only appointer who must gain the "advice" of others; the constitution provides the court's three appointees be made "with the advice of the justices." 175

The records of the appointing authorities can provide a window into the probable priorities their appointees may have. For example, Richard Corcoran has said he hopes to make school vouchers available to all parents and to impose twelve-year term limits for judges. ${ }^{176}$ Joe Negron proposed a constitutional amendment in 2012 that would abolish the CRC altogether. ${ }^{177}$ Negron was quoted as saying, "We have a revision commission. It's called the Florida Legislature." 178 Negron's proposal died in the budget committee, although it had passed the judiciary committee. ${ }^{179}$

Different appointing authorities have conducted appointments differently; evidence is scant as to the reasoning behind how many of the decisions were made. In 1977, Jim Apthorp, a 1977 CRC member who worked closely with Governor Askew throughout his terms in office, said the appointing authorities met to coordinate the appointment process, mainly to avoid overlap. ${ }^{180}$ In 1997 , according to general counsel Deborah Kearney, the appointing authorities did not coordinate among themselves as to who would appoint whom; at least, Kearney and Executive Director Billy Buzzett were unaware of any, which means that at least no other appointer coordinated with the governor's office. ${ }^{181}$ Senate President Toni Jennings, who appointed members in 1997, has said that she coordinated with House Speaker Dan Webster simply to avoid appointing overlapping people. ${ }^{182}$ Jennings has also said that she appointed herself because she saw service on the CRC as a

news/politics-government/state-politics/article58674993.html.

175 Fla. Const. art. XI, § 2(a)(4).

176 Gary Fineout, Florida House speaker designate delivers fiery speech calling for sweeping changes, FLORIDA TIMES-UNION, (Sept. 16, 2015), http://jacksonville.com/ news/2015-09-16/story/florida-house-speaker-designate-delivers-fiery-speech-callingsweeping-changes.

177 S.J. Res. 108, Reg. Sess., at 1 (Fla. 2012).

178 Negron gets support, supra note 124.

179 S.J. Res. 108, Reg. Sess., at 4 (Fla. 2012).

180 Interview with Apthorp (Jul. 23, 2015).

181 Interview with Kearney (Jul. 22, 2015); Interview with Buzzett (Aug. 10, 2015).

182 Interview with Jennings (Sept. 18, 2015) (on file with author). 
historic opportunity that no one should forego if given the chance to serve. ${ }^{183}$ On this basis, Jennings encouraged her counterpart, Dan Webster, to appoint himself to the CRC. ${ }^{184}$ However, Webster declined for a variety of reasons, but gave this advice to his appointees: "Review carefully. Review rigorously. But revise cautiously."185

Governor Chiles accorded a great deal of leeway in CRC selections to the chair he had named, who until then had been Chiles's general counsel-Dexter Douglass. ${ }^{186}$ Competition to be appointed to the 1997-98 CRC was fierce. Governor Chiles's office alone rejected past and sitting Florida Bar presidents and another prominent lawyer who would soon be appointed to the Florida Supreme Court, Raul Cantero. ${ }^{187}$ In all, Chiles had to turn down 131 applicants on the way to appointing his fifteen commissioners. ${ }^{188}$

Many who have served as commissioners have offered their opinions of what qualities an ideal commissioner should have. ${ }^{189}$ All have said that an ideal commission should have people from a variety of walks of life. ${ }^{190}$ However, several former commissioners mentioned some desirable qualities. ${ }^{191}$ A CRC member should have sufficient time to spend doing the work and attending the meetings. ${ }^{192}$ Absenteeism among 1997 members became a point of notice in the

\footnotetext{
183 Id.

184 Id.

185 M. Dyckman, From the commission, little revision: the group takes a conservative approach to its work, avoiding radical proposals and preparing a limited slate of amendments, ST. PETERSBURG TIMES (Mar. 7, 1998) [hereinafter From the commission]; An Issue No One Is Talking About In The Florida Governor's Race, CROWLEY POLITICAL REPORT (Aug. 13, 2014) http://www.crowleypoliticalreport.com/ 2014/08/an-issue-no-one-is-talking-about-in-the-florida-governors-race.html [hereinafter An Issue No One is Talking About].

186 Interview with Kearney (Jul. 22, 2015); Interview with Zack (July 13, 2015); Interview with Brochin (July 13, 2015).

187 See An Issue No One is Talking About, supra note 185.

188 Fla. St. Archives, Record Group 1006, Series 1760, Box 2.

189 Id.

190 Id

191 Id.

192 Interview with Alfonso (Dec. 14, 2015).
} 
press. ${ }^{193}$ Many former CRC members have remarked on the heavy workload of the CRC and the difficulty of being away from their families and livelihoods for the lengthy meetings. ${ }^{194}$

CRC members should have some knowledge of the constitution, according to Jim Apthorp (1977-78) and Martha Barnett (1997-98), although some appointees, such as architect Carlos Alfonso, have admitted they were not intimately familiar with the constitution when appointed by Webster. ${ }^{195}$ However, Alfonso has another quality that Barnett and D'Alemberte have identified as important: the ability to apply himself to the task and learn. ${ }^{196}$ Barnett has added that CRC members should not be politically naïve "or they'll be eaten alive."197 However, current holders of elective office may not be ideal candidates either because their desire to please their constituents or to campaign for reelection may conflict with CRC work and timetables. Additionally, a commission may adopt proposals distasteful to officeholders' constituencies which could get commissioner-officeholders in trouble with their constituency through no fault of their own.

\section{Lobbying}

Lobbying and other attempts to influence the work of constitution revision have played a role in CRCs since at least 1966, when Florida Supreme Court Justice (and former Governor) Millard Caldwell wrote to Chesterfield Smith, the chair of the 1966 CRC and head of a large law firm whose lawyers appeared before the Florida Supreme Court. ${ }^{198}$ Caldwell's request to Smith was general-it was a simple plea that the CRC make no changes to the old constitution. ${ }^{199}$ Even so, one could question the propriety of a justice asking a lawyer

\footnotetext{
193 Martin Dyckman, Commission hurt by absenteeism, ST. PetersBurg TIMES (Feb. 3,1998 ) [hereinafter Commission hurt by absenteeism].

194 See, e.g., Interview with Alfonso (Dec. 14, 2015); Interview with FernandezRundle (Oct. 2, 2015); Interview with Ford-Coates (Aug. 13, 2015).

195 Interview with Alfonso (Dec. 14, 2015).

196 Interview with Barnett and D'Alemberte (Apr. 29, 2014).

197 Id.

198 Letter from Millard F. Caldwell, J., to Hon. Chesterfield Smith (Jan.17, 1966) (available at Fla. Dep't of State, Fla. State Archives, Record Group 001006, Series 719, Carton 1, Folder 2).

199 Id.
} 
who appears before the court to do anything-after all, the justice could exact retribution for disobedience when any of Smith's firm's lawyers had a case before Caldwell's court. Although groups, such as the League of Women Voters and the statewide county tax collectors' organization, attended and had spokespersons at the public hearings the 1966 CRC conducted, little direct lobbying occurred according to 1966 CRC member (and career lobbyist) Robert M. Ervin. ${ }^{200}$

By 1977, lobbying of the CRC members began to be more noticeable and intense, probably because the CRC was seen as an effective way to bypass the legislature. ${ }^{201}$ This situation differs from that of the 1966 CRC, which had no actual power because it could only recommend its changes to the legislature. ${ }^{202}$ The $1977-78$ commission transcripts reveal instances when organizations' lobbying efforts came explicitly to the debate floor. ${ }^{203}$ One example was the 1977-78 proposal to create an independent reapportionment commission. ${ }^{204}$ On January 12, 1978, Proposal 195, which not only called for an independent reapportionment commission but also provided for all legislative districts to be single-member, was initially voted onto the ballot nearly unanimously. ${ }^{205}$ When Commissioner Yvonne Burkholtz announced she intended to move that the CRC reconsider the proposal, even though she had voted for it (a requirement under the Commission's rules), Common Cause, a political watchdog organization, promptly wrote a letter opposing the reconsideration and made sure every commissioner received a copy. ${ }^{206}$ The letter was discussed in the floor debate over whether to reconsider the commission. ${ }^{207}$

Martha Barnett was an effective lobbyist before the 1977-78 CRC, succeeding in getting a proposal on the ballot that would exempt property leased from a municipal government from taxation, even when

\footnotetext{
200 Interview with Ervin (Jan. 12, 2011).

201 See Steven J. Uhlfelder, The Machinery of Revision, 6 FLA. St. U. L. REV. 575, 575,579 (1978).

202 Id. at 575.

203 1977-78 CRC transcript, Jan. 12, 1978, at 4045-59.

204 Id.

205 Id.

206 Id.

207 1977-78 CRC transcript, Jan. 24, 1978, at 5018-34.
} 
the lessee was a private for-profit company. ${ }^{208}$ Twenty years later, she was a member of the 1997-98 CRC and found herself being lobbied for the same purpose. ${ }^{209}$ Again, the issue made it to the ballot as a proposed constitutional change. ${ }^{210}$ Again, it failed adoption, and that time it was the only proposal that failed. ${ }^{211}$ Barnett's expertise in taxation, which she used in her 1978 lobbying, made her a valuable and knowledgeable member of not only the 1997-98 CRC, but also both the 1992 and 2008 Taxation and Budget Reform Commissions. ${ }^{212}$ As a long-time lawyer and lobbyist, Barnett understood lobbyists and could hold her own against those who tried to lobby her. ${ }^{213}$ Being on the receiving end of lobbyists' efforts did not change Barnett's mind about the appropriateness of lobbying. ${ }^{214}$ She has said that lobbying amounts to the free-speech right of interest groups to provide information to decision makers. ${ }^{215}$

Despite the presence of lobbyists at the public hearings and in the halls of the Senate as the CRC and its committees met, 1997-98 member Jon Mills said that traditional lobbying, in the sense of a lobbyist having the power to contribute to one's campaign or not, was not possible. ${ }^{216}$ After all, Mills said, CRC members do not need to campaign for election or reelection to the CRC, do not have a constituency other than the entire state, and do not need to raise money related to their CRC membership. ${ }^{217}$ Therefore, lobbyists had fewer tools for influencing CRC members than they would have had for legislators. ${ }^{218}$ Nevertheless, Steven Uhlfelder, the executive director of the 1977-78 CRC, recommended to the 1997-98 steering committee that

\footnotetext{
208 Interview with Barnett and D'Alemberte (Apr. 29, 2014).

209 Id.

210 State's voters will decide amendments to constitution, SARASOTA HERALD TRIBUNE, Nov. 3, 1998 [hereinafter State's voters will decide].

211 Interview with Barnett and D'Alemberte (Apr. 29, 2014).

212 Martha Barnett, BOBGRAHAMCENTER, FSU, http://www.bobgrahamcenter.ufl.edu /content/martha-barnett.

213 Interview with Barnett and D'Alemberte (Apr. 29, 2014).

$214 \quad I d$.

215 Id.

216 Interview with Mills (July 20, 2015).

217 Id.

$218 I d$.
} 
they institute rules regarding lobbying the CRC. ${ }^{219}$ Those rules were codified into statute and remain in effect for the next CRC. ${ }^{220}$ Even with rules regarding lobbying, the 1997-98 CRC received plenty of attention from lobbyists, to the agriculture business regarding the Commissioner of Agriculture and from legislators protesting a proposed independent redistricting commission, to the NRA's persistent attempts to influence the proposed amendment on firearm background checks. ${ }^{221}$

\section{Part IV: Common Issues From 1968 To Now}

\section{A. Gun Control}

One of the subject matters that has brought the most controversy from lobbyists, if not from within the CRC, has been gun control. The right to bear arms, section 8 of article I, the Declaration of Rights, has had relatively little change since its inception in $1968 .{ }^{222}$ The state's right to regulate firearms was written into the 1968 constitution together with the right to bear arms. ${ }^{223}$ Firearm regulation has seen only two changes since, and only one of those changes appears in article I. ${ }^{224}$ That change is the 1990 legislatively proposed mandate of a three-day waiting period before the retail purchase of handguns. ${ }^{225}$ The mandate did not include a criminal history check for the purchaser; it contemplated only a cooling-off period and only for handguns. ${ }^{226}$ Commissioner Katherine Fernandez-Rundle, state attorney for MiamiDade County - the most notorious gun-slinging county in the stateproposed that the 1998 ballot should require a background check for the sale of every gun, including long guns and guns sold at gun shows. ${ }^{227}$

\footnotetext{
219 Constitutional Revision in Florida, supra note 12, at 37-38.

220 See Fla. STAT. $\$ 112.3215$ (2016).

221 Interview with Butterworth (June 25, 2015); Interview with Alfonso (Dec. 14, 2015); Interview with Brochin (July 13, 2015); Interview with Freidin (Aug. 26, 2015).

222 Daniel Gordon, Protecting Against the State Constitutional Law Junkyard: Proposals to Limit Popular Constitutional Revision in Florida, 20 Nova L. REV. 413, 417 (1995).

223 FLA. CONST. art. I, $\S 8$.

224 Id. art. I, $\S 8$, art. VIII., $\S 5$.

225 Id. art. I, §8(b).

226 Id.

227 Paul Mendelson \& Katherine Fernandez Rundle, Closing the Deadly Loopholes in
} 
However, the $1998 \mathrm{CRC}$ realized that a statewide tightening of gun accessibility might not be palatable in a state as diverse as Florida. Expanding the three-day waiting period to all firearms and adding a background check might make sense in urban areas, which were experiencing alarming growth in firearm-related homicides. But in more rural counties, the expanded requirements would insult lifelong hunters, for example. Fernandez-Rundle soon came to understand this and proposed the amendment as a county-by-county opt-in. ${ }^{228}$ The NRA was sufficiently worried about the possibility of a proposal like this that it had representatives at every public hearing the CRC held in the summer of $1997 .{ }^{229}$ Its presence was heavy-handed enough that, years later, CRC members remembered the towering presence of the NRA at every hearing. ${ }^{230}$ Newspaper accounts support this memory. ${ }^{231}$

The measure passed, over the loud dissent of the NRA's president, Marian Hammer, who lived in Tallahassee. ${ }^{232}$ Her cries, and the NRA's strong pre-election media blitz claiming the amendment would actually weaken gun-related penalties statewide, were perhaps too raucous: many decried them as false. ${ }^{233}$ No, the proposed constitutional amendment would not replace state felony penalties with county misdemeanors: the hierarchy of law makes that impossible, as the county ordinances would not replace any state laws. The measure would only close the loophole that allowed anyone to buy a gun at a gun show without having to submit to a background check. ${ }^{234}$

More than seventy percent of voting Floridians approved the proposal. ${ }^{235}$ The percentage in the three most populous countiesMiami-Dade, Broward, and Palm Beach-was well over eighty

the Firearms Laws: The History and Impact of Amendment 12, 52 FLA. L. REV 457, 459 (2000).

228 Id. at $458-59$.

229 Id. at 462.

230 Interview with Brochin (Jul. 13, 2015); Interview with Ford-Coates (Aug. 13, 2015); Interview with Zack (Jul. 13, 2015).

231 Charles Elmore, Proposal to slice up school district dies, PALM BEACH POST, Mar. 18, 1998, at 1A, 10A.

232 Id. at $1 \mathrm{~A}$.

233 Mendelson \& Rundle, supra note 227 , at 466-67.

234 Id.

235 Id. at 458. 
percent. $^{236}$ Urban counties opted in quickly, in some cases having ordinances ready to take effect the same day the new constitutional amendment would. ${ }^{237}$ On the other hand, at least one county actually repudiated the measure; Columbia County passed an ordinance proclaiming that "[a]ll county ordinances which regulate or attempt to regulate firearms and ammunition, including, without limitation, the purchase, sale, transfer, taxation, manufacture, ownership, possession, storage, and transportation thereof are hereby repealed to the extent they so regulate or attempt to so regulate." 238 Because it involved a local option, the amendment was placed in the Local Government article, article VIII, section 5. ${ }^{239}$ Two 2012 initiatives seeking to make gun ownership free from all regulation failed to reach the ballot; no other attempts to change Florida's right to bear arms have been attempted. ${ }^{240}$

\section{B. Legislative Branch}

\section{Apportionment.}

The section of the legislative article that has generated the most controversy and the most activity while attempting to change it has been section 16, having to do with how the legislative and congressional districts are apportioned. ${ }^{241}$ The 1978 CRC, which, in keeping with the politics of its time, was composed mostly of Democrats, voted to put an Independent Reapportionment Commission ("IRC") on the ballot for adoption. ${ }^{242}$ Conventional wisdom holds that independent reapportionment commissions are bad for the majority party because they will take control away from that party and place it in neutral hands. The 1977-78 CRC stood to lose power for the Democratic Party if the

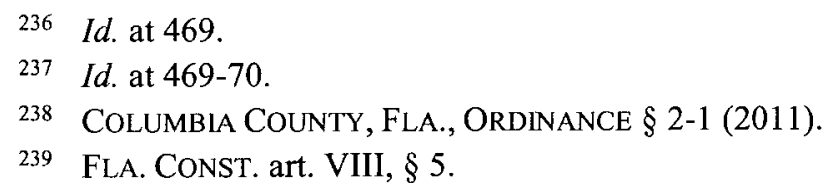

240 Division of Elections, Initiatives/Amendments/Revisions, FLA. DEP'T ST., http://do s.elections.myflorida.com/initiatives/ (last visited May 31, 2016) [hereinafter Initiatives/Amendments/Revisions].

241 FLA. CONST. art. III, $\S 16$.

242 See A Retrospective and Prospective Sketch, supra note 143 (indicating that main contributors to the formation of 1977-78 CRC were Democrats); LINDA HONOLD \& Adrien Schless-Meier, Case Studies of State Redistricting Campaigns 4 (2015) (stating that the IRC plan was on the ballot in the $1978 \mathrm{CRC}$ ). 
IRC was adopted. ${ }^{243}$ However, the evidence is mixed as to whether the conventional wisdom is accurate. Jeremy Buchman, in his book Drawing Lines in Quicksand, has suggested that IRCs adopted in a government dominated by one party actually result in fewer incumbents retaining office in the first election after a redistricting. ${ }^{244}$ When a mixed government uses an IRC for districting, Buchman suggests, the result at the next election is that more incumbents of each party retain their seats, possibly because bipartisan commissions may practice bipartisan gerrymandering. ${ }^{245}$ However, a more recent author states that studies conducted during the first decade of the twenty-first century suggest that plans drawn by redistricting commissions produce more competitive seats - that is, fewer "safe" seats for one party or another, and fewer reelections of incumbents - than plans drawn by legislators. ${ }^{246}$

Several types of redistricting commissions exist; were a 2017-18 $\mathrm{CRC}$ to consider one, it could choose to create a commission that is advisory only; a commission that acts only as a backup, if the legislature cannot agree on a plan; or a commission that is the primary body that redistricts. ${ }^{247}$ The makeup of redistricting commissions similarly may vary: some are composed of equal numbers of representatives from each political party; others are composed of equal numbers from each party who then must choose another "tiebreaker" member; still others provide that particular public officeholders appoint members or that particular officeholders actually comprise the commission. ${ }^{248}$

243 See generally Reapportionment, Redistricting, And Electors, LEADERSHIP CONF. (June 28, 2016, 11:00 PM), http://www.civilrights.org/census/your-community/redistri cting.html?referrer=https://www.google.com/ (explaining how independent commission affects majority party, which in this instance was the democratic party in 1978).

244 Jeremy Buchman, Drawing Lines in Quicksand: Courts, Legislatures, \& REDISTRICTING 214-19 (2001).

245 Id.

246 Charles S. Bullock, III, Redistricting: The Most Political ACtivity in AMERICA 136 (2010).

247 Justin Levitt, All About Redistricting, LOY. L. SCH., http://redistricting.lls.edu/ who.php (last visited May 31, 2016).

248 Peter Miller \& Bernard Grofman, Redistricting Commissions in the Western United States, 3 UC IRVINE L. REV. 637, 648 (2013). 
The IRC, under consideration in 1977-78, the CRC considered was an example of the "tiebreaker" type of commission. ${ }^{249}$ Its sponsor, Commissioner Jon Moyle, Sr., described it as establishing standards, prohibiting gerrymandering, establishing a nonpartisan commission, and providing prompt judicial review. ${ }^{250}$ He described it as improving independence and efficiency, cutting costs, and putting Florida in the national forefront of fair apportionment. ${ }^{251}$ The proposal generated no floor debate and passed with only one "no" vote. 252 However, less than two weeks later, Commissioner Yvonne Burkholtz moved to reconsider it. $^{253}$ The debate over whether to reconsider the IRC did generate debate, but almost none of it had to do with whether having one was a good idea. ${ }^{254}$ Burkholtz wished to change a provision governing the consequences of the reapportionment commissioners' inability to choose a tiebreaking chair. ${ }^{255}$ Discussion over how to tweak that language took up most of the debate. ${ }^{256}$ Only toward the end of the debate did Commissioner John Ryals speak up; he announced he had been the only "no" vote originally and called the IRC a "terrible, terrible proposal" and a "mistake." 257 He did not explain his reasons for saying so. ${ }^{258}$ However, opponents to IRCs typically argue that appointers will simply choose representatives as partisan as they are or alternatively that a neutral commission drawing a map of evenly divided districts will only create unhappy voters. ${ }^{259}$ Proponents of the second reason argue that drawing districts that are "safe" for one party or the other will result in a higher percentage of voters who are happy with the winning candidate and thus will be happier citizens. ${ }^{260}$ No IRC was attempted again until 1998, but reapportionment saw amendment

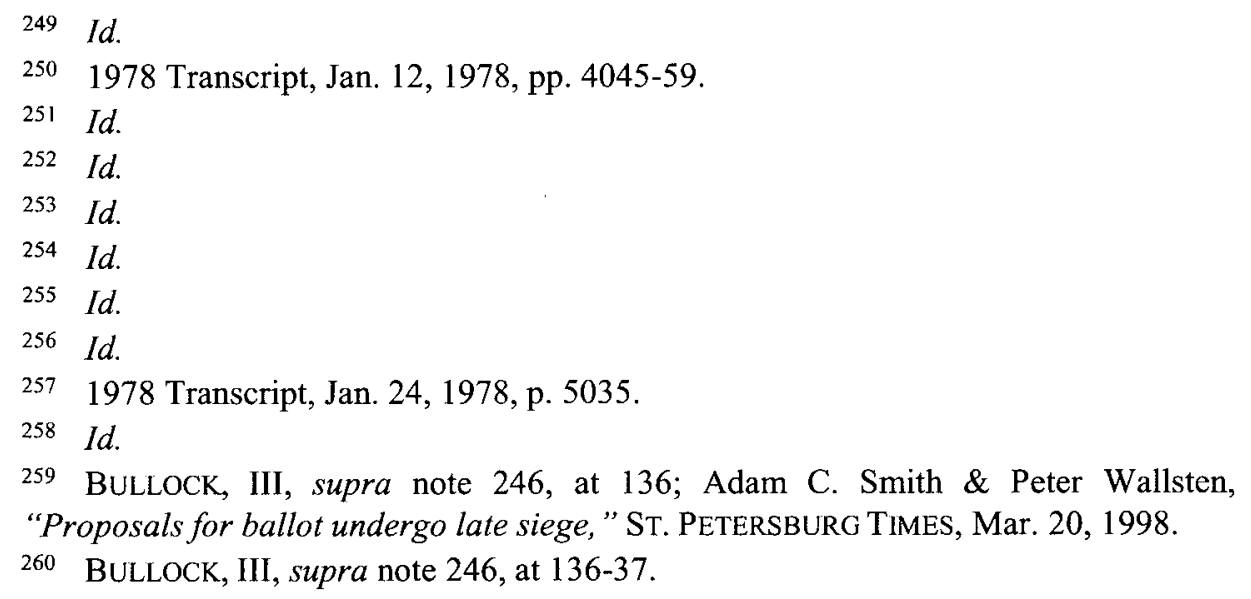


attempts in every election cycle after 1998 until the Fair Districts Amendments passed (creating two new sections to the Article and creating detailed rules for districting) in $2010 .{ }^{261}$

A proposal to have an IRC almost reached the ballot through the 1998 CRC. $^{262}$ Jennings appointee Marilyn Evans-Jones's project, an independent reapportionment commission, had a hard time getting the supermajority of twenty-two votes that it needed. ${ }^{263}$ Frank Morsani, another Jennings appointee, supported it, but all of the "no" votes as of February 12, 1998, were appointees of either Jennings, the Republican Senate President, or Webster, the Republican House Speaker. ${ }^{264}$

Toni Jennings has said that she never appointed people whom she expected to walk a particular line. ${ }^{265}$ Although she had appointed Marilyn Evans-Jones, she made no attempt to control the subjects she became involved in. ${ }^{266}$ Evans-Jones herself, a former Republican legislator from Brevard County, took some partisan flak for her work. ${ }^{267}$ When the IRC first received the twenty-two-vote supermajority it required to appear on the ballot, a newspaper article reported that an unnamed Republican approached Evans-Jones and stated: "Congratulations. You have just destroyed the Republican Party."268

After the proposal got the bare twenty-two votes it needed in March 1998, the approved measures were crafted and drafted by the Style and Drafting Committee in group drafting sessions. ${ }^{269}$ In the meantime, legislators John Thrasher and Ken Plante (who had been a CRC member in 1977-78) belatedly realized the redistricting

261 FLA. CONST. art. III, § 16; Initiative/Amendments/Revisions, supra note 240.

262 W. Dexter Dauglass, 1997-98 Constitution Revision Commission: A Progress Report, 6 FLA. B. J. 14, 14 (1998).

263 Constitution Revision Commission Proposals Filed, CONST. REVISION COMMISSION 10 (1997-1998); Dauglass, supra note 262.

264 Martin Dyckman, Redistricting for the elected few, ST. PETERSBURG TIMES (Feb.

12, 1998), at 19.A.

265 Interview with Jennings (Sept. 18, 2015).

$266 I d$.

267 Id

268 Martin Dyckman, Appointees don't always do as told, ST. PETERSBURG TIMES (Mar. 19, 1998).

269 Interview with Mills (July 20, 2015). 
commission was about to go on the ballot. ${ }^{270}$ They began talking to commissioners, including Ander Crenshaw, who had sponsored a similar bill in the Senate a few years earlier, to reconsider. ${ }^{271}$ Thrasher and company were able to get the CRC's permission to reconsider the vote in May. ${ }^{272}$ Outlandish threats and promises were made. ${ }^{273}$ For example, CRC member William "Clay" Henderson, an environmental lawyer from North Florida and an officer with the Audubon Society, said Thrasher suggested that a change to a "no" vote might result in the legislature agreeing to destroy the Rodman Dam. ${ }^{274}$ The Rodman Dam had been a sore point for environmentalists since it was built in the 1960 s as part of the aborted Cross Florida Barge Canal Project; destroying it would mean restoring the Ocklawaha River to its natural state, a long-fought-for dream for many. ${ }^{275}$ State Representative Tom Feeney, who would become House Speaker after John Thrasher, called the IRC a "really horrible policy" and, not afraid to be more explicit than Commissioner Ryals twenty years earlier, stated, "I can guarantee you that both parties are not going to pick academics. They're not going to pick independent, fair-minded people. They're going to pick eight highly partisan puppet apparatchiks."276

This time, two former "yea" votes turned. ${ }^{277}$ One was Stanley Marshall, often described as the CRC's most conservative member, and the other was Miami-Dade State Attorney Katherine Fernandez-Rundle, who took a walk, leaving the building so she would not be obligated to vote on the proposed amendment. ${ }^{278}$ The IRC did not make it to the

\footnotetext{
270 Id.

271 Martin Dyckman, "Who Should Draw the Lines?," St. Petersburg Times, Feb.

8, 1998; Interview with Barnett and D'Alemberte (Apr. 29, 2014).

272 Interview with Barnett and D'Alemberte (Apr. 29, 2014).

273 Interview with Henderson (Oct. 8, 2015).

274 Id.

275 Id.

276 Interview with Fenney.

277 Interview with Barnett and D'Alemberte (Apr. 29, 2014); Interview with Freidin (Aug. 26, 2015); Interview with Buzzett (Aug. 10, 2015); Interview with Kearney (Jul. 22, 2015).

278 Charles Elmore, "Panel rejects plan to have committee draw districts," PALM BEACH Post, Mar. 24, 1998; Interview with Barnett and D'Alemberte (Apr. 29, 2014); Interview with Freidin (Aug. 26, 2015); Interview with Buzzett (Aug. 10, 2015); Interview with Kearney (Jul. 22, 2015).
} 
ballot. $^{279}$ Fernandez-Rundle said her Latino and African-American constituents feared they would have less representation under an independent commission than under legislature-driven reapportionment. ${ }^{280}$

Many CRC members have said the IRC was the only subject in which politics caused some members to vote something other than their conscience. ${ }^{281}$ Butterworth, among others, has said he believes that if it had made it to the ballot it would have passed. ${ }^{282}$ Carlos Alfonso has mused that the Republicans' control of both houses of the legislature was simply too new, after decades of Democratic control, to give up power to a neutral body so soon. ${ }^{283}$ Many believe it will be brought up again in the 2017-18 CRC, along with other proposed amendments regarding redistricting, particularly in light of the repeated problems the legislature and the Florida Supreme Court have had in agreeing about what qualities of a legislative plan meet constitutional muster. ${ }^{284}$

The failure of the IRC in 1998 led directly to the Fair Districts Amendments that were adopted in 2010. ${ }^{285}$ CRC member Ellen Freidin, who was known in the 1998 CRC primarily for her involvement in ensuring equal rights language for women in the Declaration of Rights, watched as the politics brought the redistricting commission down. ${ }^{286}$ She saw that even a bipartisan CRC could not succeed in putting forward a mechanism to take redistricting out of the hands of persons who had reelection on their minds. ${ }^{287}$ When calculated by appointing authority, the CRC membership was eighteen

\footnotetext{
279 See generally A Retrospective and Prospective Sketch, supra note 143 (identifying the proposals on the ballot for 1977-78 wherein the redistricting or fair district initiative is missing).

280 See Elmore, supra note 278.

281 Interview with Ford-Coates (Aug. 13, 2015); Interview with Butterworth (June 25,2015 ).

282 Interview with Butterworth (June 25, 2015).

283 Interview with Alfonso (Dec. 14, 2015).

284 See Elmore, supra note 278.

285 Redistricting Provisions of the Florida Constitution, FAIR DISTRICTS NOW https://www.fairdistrictsnow.org/redistricting/amendments/ (last visited June 28, 2016).

286 Interview with Freidin (Aug. 26, 2015).

287 Id.
} 
Republicans, appointed by the first combination of Republican Speaker of the House and Republican Senate President; sixteen Democrats - the Democrat attorney general and the fifteen appointees of Democrat Governor Lawton Chiles; and three nonpartisans, but widely considered to be Democrat, appointees of Chief Justice Gerald Kogan. ${ }^{288}$

After seeing the defeat of an IRC at the hands of a bipartisan and independent $\mathrm{CRC}$, proponents attempted to accomplish the same goal through citizens' initiatives. ${ }^{289}$ The 2002, 2004, and 2006 election cycles saw unsuccessful initiatives for IRCs as well as for stricter districting standards. ${ }^{290}$ In 2006, an initiative for a "nonpartisan" commission for legislative and congressional districting was invalidated as misleading, as most of the members of the proposed commission would in fact be members of a political party. ${ }^{291}$ In 2006 the legislature placed a proposed amendment on the ballot that would require a sixty percent majority of the voting public to approve a measure for it to become a constitutional amendment. ${ }^{292}$ That amendment passed in 2006, making amendments that would change districting standards harder to pass. ${ }^{293}$ In 2007, Freidin took the helm of the redistricting ship and marketed the districting standards proposals as the Fair Districts Now Amendments. ${ }^{294}$ The legislature challenged the proposed amendments in court unsuccessfully. ${ }^{295}$ Finally, in 2010, the measures appeared on the ballot. ${ }^{296}$ Another similarly titled proposed amendment submitted by the legislature was to appear next to the Fair Districts Now! Amendments, but the Florida Supreme Court invalidated it as

\footnotetext{
288 Overview of Florida's Constitution Revision Commission, supra note 93.

289 Interview with Freidin (Aug. 26, 2015).

290 Id.

291 Advisory Op. to the Attorney Gen. Re: Indep. Nonpartisan Comm'n to Apportion Legislative and Congressional Dist. Which Replaces Apportionment By Legislature, 926 So. 2d 1218, 1220-21 (Fla. 2006).

292 Requiring Broader Public Support for Constitutional Amendments on Revisions, FLA. DEP'T ST., http://dos.elections.myflorida.com/initiatives/initdetail.asp?account= $10 \&$ seqnum $=63$ (last visited May 31, 2016).

293 FLA. CONST. art. XI, § 5(e).

294 Interview with Freidin (Aug. 26, 2015).

295 Id.

296 Howard Troxler, A look at the nine amendments on the Florida Ballot, THE TAMPA BAY TIMES (May 29, 2010).
} 
misleading, holding that it failed to clearly disclose that its purpose was to nullify the Fair Districts Now Amendments. ${ }^{297}$ More than sixty percent of the voters adopted the Fair Districts Now Amendments. ${ }^{298}$

Why was the legislature so hostile to the Fair Districts Now Amendments? The amendments have specific requirements to determine whether districts are fairly drawn. ${ }^{299}$ In other words, they make the job of the legislators much harder, while also making it hard to draw districts that help one political party over the other. The full text of the new section 21 is set forth below. ${ }^{300}$ The text of new Section 20 is identical with the exception that it pertains to congressional districts, not Florida legislative districts. ${ }^{301}$

SECTION 21. Standards for establishing legislative district boundaries. — In establishing legislative district boundaries:

(a) No apportionment plan or district shall be drawn with the intent to favor or disfavor a political party or an incumbent; and districts shall not be drawn with the intent or result of denying or abridging the equal opportunity of racial or language minorities to participate in the political process or to diminish their ability to elect representatives of their choice; and districts shall consist of contiguous territory.

(b) Unless compliance with the standards in this subsection conflicts with the standards in subsection 1(a) or with federal law, districts shall be as nearly equal in population as is practicable; districts shall be compact; and districts shall, where feasible, utilize existing

\footnotetext{
297 Fla. Dep't of State v. Fla. State Conference of NAACP Branches, 43 So. 3d 662, 669 (Fla. 2010).

298 Standards for Legislature to Follow in Congressional Redistricting, FLA. DEP'T ST., http://dos.elections.myflorida.com/initiatives/initdetail.asp?account=43605\&seq num=1 (last visited May 31, 2016); Standards for Legislature to Follow in Legislature Redistricting, FLA. DEP'T ST., http://dos.elections.myflorida.com/initiatives/initdetail. asp?account $=43605 \&$ seqnum $=2$ (last visited May 31, 2016).

299 FLA. CONST. art III, § 16(a).

$300 \quad I d . \S 21$.

$301 \quad I d . \S \S 20-21$.
} 
political and geographical boundaries.

(c) The order in which the standards within subsections $1(a)$ and (b) of this section are set forth shall not be read to establish any priority of one standard over the other within that subsection. ${ }^{302}$

While the measures passed with a wide margin, they have been litigated since, with the Florida Supreme Court invalidating legislatively drawn districts in 2012, 2014, and 2015. ${ }^{303}$ The difficulty the legislature has had in drawing districting plans that the Florida Supreme Court finds constitutional highlights, in the views of many, the need for an IRC.

\section{Frequency of Sessions}

In 1978 Commissioner Dubose Ausley proposed a return to biennial legislative sessions. ${ }^{304}$ His reasoning: quoting fellow commissioner and legislator, Ken Plante, Ausley pointed out that every law passed by the legislature restricts one's personal freedom. ${ }^{305}$ Also, Ausley pointed to the modern, post-1968, well-staffed legislature and pointed out that with the legislature's current staff support, the job of governing Florida or setting policies for it could, as before the 1968 constitution was implemented, be done in sixty days every two years. ${ }^{306}$ Ausley also pointed out, in an apparent attempt to demonstrate his lack of bias, that by suggesting the change back to biennial sessions, he would "be in trouble with" his law firm, which, as he put it, made money trying to figure out what the legislature passes each session. ${ }^{307}$ However, Ausley's proposal never made it to the ballot. ${ }^{308} \mathrm{Had}$ it been adopted, Florida's annual legislative sessions would have been only a ten-year anomaly in an otherwise steady pattern of biennial sessions. ${ }^{309}$

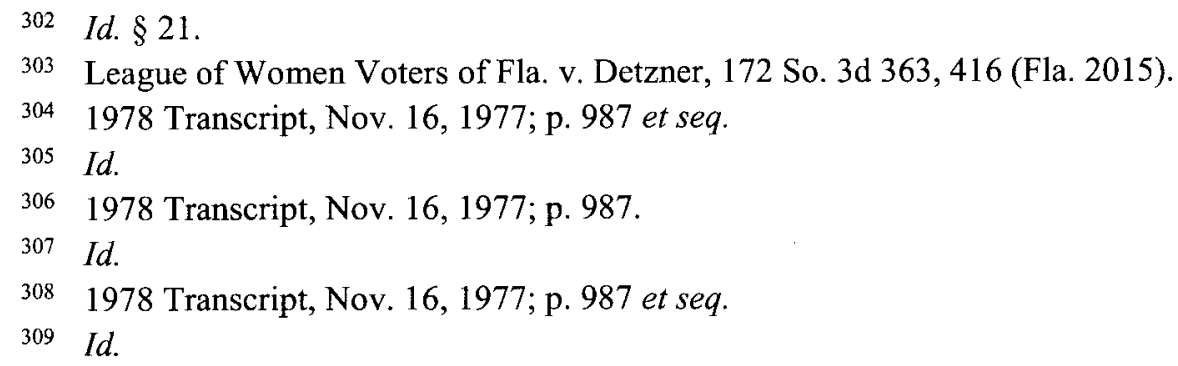




\section{Executive Branch}

\section{Cabinet}

The most significant change to the Executive Branch since its major reorganization in the 1968 constitution has been the reduction of the number of officials elected statewide in addition to the governor. ${ }^{310}$ From the inception of the 1885 constitution until 1992, these officials, collectively referred to as the cabinet, had no limit to the number of terms they could serve, making them arguably more powerful than the governor, who could not succeed himself at all under the 1885 constitution and was limited to two terms under the 1968 constitution. $^{311}$ Not until 1992 was the constitution amended to limit cabinet members to eight years. ${ }^{312}$ Whether to reduce the number of the elected members of the Cabinet made for some of the most heated discussion not only in the 1966 CRC, which ultimately kept it intact, but also in both the 1977-78 CRC and the 1997-98 CRC.

Jon Moyle, Sr., a gubernatorial appointee for the 1977-78 CRC, has acknowledged he acted as Governor Reubin Askew's floor manager on issues important to the governor. ${ }^{313}$ However, he had one notable failure to accurately count votes on a politically sensitive topic: whether and how to reduce the cabinet. ${ }^{314}$ The CRC was divided between members who wanted to abolish the elected cabinet, making its members appointed by the governor, and members who wished to keep it elected. ${ }^{315}$ But even those who wanted the cabinet abolished realized that such a radical move, greatly strengthening the governor, would be politically unpalatable and was likely to lose on voting day. ${ }^{316}$ Therefore, led by Moyle, who was carrying out the governor's

\footnotetext{
310 See The Governor and Cabinet: STRUCTURE OF THE FLORIDA CABINET, MY FLORIDA, http://www.myflorida.com/myflorida/cabinet/structurehistory.html (last visited June 28, 2016) (explaining the reduction of cabinet members directly elected by the Florida electorate to its modern three officers) [hereinafter The Governor and Cabinet].

311 FLA. CONST. of 1885, art. IV, $\S 2$; FLA. CONST. of 1968, art. IV, §5(b).

312 FLA. CONST. of 1992, art. VI, $\S 4$.

313 Interview with Jon C. Moyle, Sr. (June 22, 2014).

314 Id.

315 Id.

316 Id.
} 
preference, they proposed a halfway measure that would reduce the cabinet to three members. ${ }^{317}$ Supporters for retaining the full elected cabinet, led by Dempsey Barron, tried the reverse tactic of sponsoring an amendment to fully abolish the cabinet. ${ }^{318}$ Commissioner Moyle believed there were sufficient votes on the $\mathrm{CRC}$ to defeat the no-cabinet amendment - but Moyle had not polled Chairman D'Alemberte, his old friend from law school. ${ }^{319}$ Unknown to Commissioner Moyle, the chairman had pledged his vote to Commissioner Barron that he would support either abolishing the cabinet entirely or leaving it untouched, but only if the CRC vote was tied and the chair's vote was needed. ${ }^{320}$ That is exactly what happened. ${ }^{321}$ Chairman D'Alemberte cast the final vote that passed the amendment to abolish the whole cabinet. ${ }^{322}$ The vote was nineteen to eighteen. ${ }^{323}$ Faced with the governor's disappointment, and surprised by D'Alemberte's vote, Moyle was furious. ${ }^{324}$ D'Alemberte proposed the two men play racquetball together to heal the division. ${ }^{325}$ D'Alemberte recalls that every chance he got, Moyle tried to butt D'Alemberte into the concrete court walls. ${ }^{326}$ D'Alemberte said later, "Jon was much bigger and stronger than I, but I was a better racquetball player." ${ }^{27}$ Moyle remembers this incident in exactly the same fashion. ${ }^{328}$

The cabinet finally shrank as a result of the 1998 CRC. ${ }^{329}$ But the impetus came from within the cabinet. During the public hearings

\footnotetext{
317 Id

318 Id.

319 Id.

$320 \quad I d$

321 Id.

322 Id

$323 I d$.

$324 \mathrm{Id}$.

325 Interview with Barnett and D'Alemberte (Apr. 29, 2014).

326 Id.

$327 \mathrm{Id}$

328 See interview with Barnett and D'Alemberte (Apr. 29, 2014); Interview with Moyle (June 22, 2014); MARTIN DYCKMAN, REUBIN O'D. ASKEW AND THE GOLDEN AGE OF FLORIDA POLITICS 245-46 (University Press of Florida 2011).

329 Florida Cabinet: 1845-present, FLORIDA MEMORY, https://www.floridamemory .com/collections/governors/florida-cabinet.php (last visited June 20, 2016).
} 
in the summer of 1997, before the CRC began its deliberations, thenInsurance Commissioner Bill Nelson and Comptroller Robert Milligan testified that their positions should be combined into one position, the state's chief financial officer. ${ }^{330}$ This move would take the number of cabinet members from six to five. ${ }^{331}$ At least one CRC member who was a cabinet member at the time, Attorney General Bob Butterworth, reasoned that because the attorney general and the chief financial officer positions both require technical expertise that is essentially apolitical, they are appropriate for statewide election. ${ }^{332}$ Reducing the cabinet to only the attorney general and chief financial officer would have eliminated the commissioner of education, the secretary of state, and the commissioner of agriculture from elective office. ${ }^{333}$

This scheme seemed headed for the ballot in early 1998 when it hit a snag: agribusiness noticed it. ${ }^{334}$

One day, nineteen representatives of various agricultural interests entered the office of Carlos Alfonso, who was chair of the executive committee, which sponsored the cabinet-reduction bill. ${ }^{335}$ Their spokesman told Alfonso: If you want to live in this state, you'll not take the Agricultural Commissioner off the cabinet, because if you do, we will not only wreck your proposal but we will also wreck you. ${ }^{336}$ Agricultural representatives also visited the office of CRC Chair Dexter Douglass with the same message. ${ }^{337}$ Alfonso has described meeting with the agriculture representatives and reasoning with them. ${ }^{338}$ However, they received what they wanted: the commissioner of

\footnotetext{
330 Interview with Butterworth (June 25, 2015); Martin Dyckman, Agribusiness defends its turf, ST. PetersBuRG TIMES, Feb. 22, 1998 [hereinafter Agribusiness defends its turf].

331 Interview with Butterworth (June 25, 2015).

332 Id.

333 The Governor and Cabinet, supra note 310 (stating that there are only three elected positions and the governor appoints two other positions).

334 Agribusiness defends its turf, supra note 330.

335 Fish \& Wildlife Foundation of Florida: Carlos Alfonso, FisH\&WILDLIFE, http://www.fishwildlifeflorida.org/alfonso/ (last visited June 28, 2016).

336 Interview with Alfonso (Dec. 14, 2015).

337 Agribusiness defends its turf, supra note 330.

338 Interview with Alfonso (Dec. 14, 2015).
} 
agriculture is still an elected cabinet member. ${ }^{339}$ The CRC eventually placed on the ballot, and the voters adopted, a provision in which the elected Secretary of State and Education Commissioner positions would sunset at the same time their current occupants' terms would expire. ${ }^{340}$ In turn, people holding those positions would have no personal incentive to oppose the new plan. ${ }^{341}$

\section{Other Executive Branch Issues.}

The largest remaining change to the executive branch was the merger of the Marine and Salt Water Fisheries Commission and the Game and Freshwater Fish Commission. ${ }^{342}$ Changes had been attempted in 1996, but it was the 1998 CRC that finally melded the two groups' jurisdictions into the new entity called the Fish and Wildlife Conservation Commission. ${ }^{343}$ For the first time, the same authority administered marine, freshwater, and land wildlife, and their funding sources were defined and constitutionally protected. ${ }^{344}$ The governor appoints each of the seven positions; they set policy but the legislature sets details such as seasons and bag limits. ${ }^{345}$ In turn, the constitution directs the legislature to use all hunting and fishing-related revenues for the "management, protection, and conservation" of marine, freshwater, and land wildlife. ${ }^{346}$

In 1988, the legislature added two sections to the executive branch, creating the Department of Veterans' Affairs and the Department of Elderly Affairs. ${ }^{347}$ These two departments were

\footnotetext{
339 The Governor and Cabinet, supra note 310.

340 FLA. CONST. of 1968, art. VI $\S 4$ (revised 1992).

341 Id.

342 State Archives of Florida Online Catalog, FLA. DEP'T ST., http://archivescatalog. info.florida.gov/default.asp?IDCFile=/fsa/DETAILSS.IDC,SPECIFIC=627763,DATA BASE=SERIES (last visited June 20, 2016).

343 FLA. CONST. of 1986, art. IV, $\S 9$ (revised 1998) (dictating that all wildlife falls under this section of the Florida Constitution).

344 Id.

345 See id.

346 Id.

347 See generally H.R.J. Res. 290, Fla. Revision Comm'n (Fla. 1988), http://fall.fsulawrc.com/crc/conhist/1988amen.html (adding the Department of Veterans' Affairs and the Department of Elderly Affairs to the resolution).
} 
evidently seen universally as necessary for constitutional creation and protection, as neither has been challenged since.

\section{Suffrage and Elections}

The changes to the constitutional provisions for suffrage and elections have been few but profound. As with the rest of the constitution, attempts at changes using the citizens' initiative process have been many; however, most have been unsuccessful for one reason or another at reaching the ballot. ${ }^{348}$ Only one initiative reached the ballot, only to fail; that was an initiative to repeal the 1998 amendment requiring the legislature to create a plan for "public financing for campaigns for statewide office." 349

\section{Term Limits}

The first major change to the elections law was the successful 1992 initiative creating term limits for cabinet members, legislators, U.S. Senators, and members of Congress. ${ }^{350}$ The eight-year term limit cannot actually bind U.S. Senators and Representatives, as they are bound by the United States Constitution and not by the Florida Constitution for purposes of their service. ${ }^{351}$ To actually bind them to eight years would arguably hobble Florida's effectiveness in Congress, as it would restrict its congressional delegation to far fewer years than those from other states, keeping Floridians out of the influential positions that depend on seniority.

The disadvantage a Florida Congress person would experience with a term limit disappears when it applies to the entire legislature of Florida; all Florida state legislators are on common ground with their eight-year limits. ${ }^{352}$ The disadvantages are different, critics argue. If

348 See Initiatives/Amendments/Revisions, supra note 240.

349 Division of Elections, Ballot Access, Public Campaign, Financing, \& Election Process Revisions, FLA. DEP'T ST., http://dos.elections.myflorida.com/initiatives/ (last visited June 23, 2016) [hereinafter Ballot Access, Public Campaign].

350 FLA. CONST. of 1992, art. VI, $\S 4$.

351 See U.S. CONST. art. VI, cl. 2 (stating that the Constitution is the supreme law of the land).

352 See generally FLA. CONST. of 1992, art. VI, $\S 4$ (1992) (stating that the state legislators have a term of eight years). 
legislators must leave in eight years, then the leadership of each house must rise to the top in only six years. This means that ambitious candidates must begin politicking for leadership positions, even for speaker of the house and president of the senate, in some cases before they even are elected. Instead of learning the ropes and earning respect over years of committee service, they are strategizing to move up through the ranks. The result can be a legislature that responds primarily to its own power structure rather than to the needs of the state, according to critics of the term limits. ${ }^{353}$ Since 1992, several attempts have been made to repeal the term limits amendment. ${ }^{354}$ But the melody of "Throw the bums out!" is catchier than the complex reasons a legislator might better serve his or her constituents by learning how to serve effectively over a longer arc of time. ${ }^{355}$ A proposal to relax term limits may be on the 2017-18 CRC's agenda. ${ }^{356}$

\section{Other Issues}

The 1998 CRC's ticket of proposals included one reforming election law that affected sections 1,2, 5, and 7 of article VI. ${ }^{357}$ Among other things, it equalized ballot access requirements for independent and minor party candidates with that of majority party candidates; allowed all voters to vote in a primary election if no other candidate was running; provided public financing of campaigns for statewide candidates who would agree to campaign spending limits; permitted gubernatorial candidates to run in primary elections without a running mate; and made school board elections nonpartisan. ${ }^{358}$ It, like most of

353 See generally Randall G. Halcombe, Since term limits took effect, state government has shrunk, ORLANDO SENTINEL (Mar. 25, 2015) http://www.orlandose ntinel.com/opinion/os-ed-term-limits-florida-032515-20150324-story.html (explaining that legislative staff favor government spending and programs because the staffers work for the legislators and therefore have preference for their own power structure).

354 See generally Mary Ellen Klas, Florida legislators propose increasing term limits, MIAMI HERALD, (Nov. 20, 2015, 12:50 PM), http://www.miamiherald.com/new s/politics-government/state-politics/article45621033.html (discussing that the Florida Supreme Court upheld the eight-year term limit in 1995 when the U. S. Supreme Court did away with term limits for Congress).

355 See generally id. (using the similar phrase "Throw out the Rascals").

356 Id.

357 See Ballot Access, Public Campaign, supra note 349.

358 State's voters will decide, supra note 210. 
the 1997-98 CRC's proposals, was adopted by the voters by a healthy margin. ${ }^{359}$

Other ballot initiatives that have been attempted and that may arise again have involved several initiatives seeking to expand voting rights, such as initiatives that would have allowed parents to vote on behalf of their children and guardians to vote on behalf of the incapacitated adults they care for; restored voting rights for felons; and lowered the voting age to sixteen. ${ }^{360}$ Others sought to increase options for voters in the voting booth, allowing for a "none of the above" line on ballots; allowing for recall votes; and creating an instant runoff by allowing people to vote for their first and second place candidates, as Florida law currently provides for plurality wins in general elections. ${ }^{361}$

\section{PART V: Conclusion}

A review of all revisions and attempted revisions to the Florida Constitution since 1968 is beyond the scope of this Article. Many other issues, such as the constitutional right to privacy, may come under scrutiny by the next CRC. Other issues, such as the judiciary and education, are treated elsewhere in this symposium issue. When the 2017-18 CRC steps into the river of constitution revision next year, the author's hope is that this Article and the other articles in this Volume will help their understanding of the issues critical to Florida.

\footnotetext{
359 See Ballot Access, Public Campaign, supra note 349.

360 See generally Initiatives/Amendments/Revisions, supra note 240 (listing the past and present initiatives, amendments, and revisions that have failed).

361 See generally id. (listing the past and present initiatives, amendments, and revisions).
} 
